\title{
Doustne antykoagulanty nowej generacji - aspekty praktyczne Stanowisko Sekcji Farmakoterapii Sercowo-Naczyniowej Polskiego Towarzystwa Kardiologicznego
}

\author{
Novel oral anticoagulants - practical aspects. Consensus from \\ Cardiovascular Pharmacotherapy Section of the Polish Cardiac Society
}

\author{
Jarosław D. Kasprzak ${ }^{1}$, Rafał Dąbrowski ${ }^{2}$, Marcin Barylski ${ }^{3}$, Artur Mamcarz $^{4}$, Marcin Wełnicki ${ }^{4}$, \\ Krzysztof J. Filipiak ${ }^{5}$, Piotr Lodziński ${ }^{5}$, Dariusz Kozłowski ${ }^{6}$, Beata Wożakowska-Kapłon ${ }^{7,8}$ \\ ${ }^{1}$ Katedra i Klinika Kardiologii Uniwersytetu Medycznego w Łodzi \\ ${ }^{2}$ II Klinika Choroby Wieńcowej Instytutu Kardiologii w Warszawie \\ ${ }^{3}$ Klinika Chorób Wewnętrznych i Rehabilitacji Kardiologicznej Uniwersytetu Medycznego w Łodzi \\ ${ }^{4}$ III Klinika Chorób Wewnętrznych i Kardiologii II Wydziału Lekarskiego Warszawskiego Uniwersytetu Medycznego \\ ${ }^{5}$ I Katedra i Klinika Kardiologii Warszawskiego Uniwersytetu Medycznego \\ ${ }^{6}$ Klinika Kardiologii i Elektroterapii Serca Gdańskiego Uniwersytetu Medycznego \\ ${ }^{7}$ Klinika Kardiologii i Elektroterapii Świętokrzyskiego Centrum Kardiologii w Kielcach \\ ${ }^{8}$ Wydział Lekarski i Nauk o Zdrowiu Uniwersytetu Jana Kochanowskiego w Kielcach
}

\section{Streszczenie}

Niniejszy dokument jest stanowiskiem Sekcji Farmakoterapii Sercowo-Naczyniowej Polskiego Towarzystwa Kardiologicznego na temat praktycznego stosowania nowych doustnych antykoagulantów - antagonistów trombiny i czynnika Xa, z uwzględnieniem najnowszych danych, w tym wytycznych Europejskiego Towarzystwa Kardiologicznego i rekomendacji Europejskiej Asocjacji Rytmu Serca.

Słowa kluczowe: NOAC, antykoagulanty, migotanie przedsionków

Folia Cardiologica 2016; 11, 5: 377-393

\section{Nowa generacja doustnych leków przeciwzakrzepowych}

Od czasu wprowadzenia do terapii w 1954 roku warfaryny antagoniści witaminy K (VKA, vitamin K antagonists) stali się podstawowymi doustnymi lekami przeciwzakrzepowymi, mimo licznych praktycznych problemów. Najważniejsze z nich to konieczność indywidualnego doboru dawki i monitorowania pożądanej siły działania za pomocą laboratoryjnej oceny wydłużenia czasu protrombinowego (PT, pro- thrombin time), długi i nieprzewidywalny czas działania po ostatniej dawce, brak antidotum szybko odwracającego efekt przeciwzakrzepowy, mnogość interakcji z lekami i pokarmem oraz zmienność efektu przeciwzakrzepowego w czasie. Mimo tych wad VKA szeroko stosowano w przypadku braku alternatywnej terapii niewymagającej podawania parenteralnego. Wieloletnie doświadczenia z praktycznym stosowaniem VKA (np. acenokumarolem, warfaryną, fenprokumonem) potwierdziły nie tylko ich skuteczność w zapobieganiu zakrzepicy żylnej oraz zatorowości sercopochodnej

Adres do korespondencji: prof. dr hab. n. med. Jarosław D. Kasprzak, FESC, FACC, Katedra i Klinika Kardiologii, Uniwersytet Medyczny w Łodzi, Szpital im. Biegańskiego, ul. Kniaziewicza 1/5, 91-347 Łódź, tel. 4225160 15, e-mail kasprzak@ptkardio.pl 
w migotaniu przedsionków (AF, atrial fibrillation), ale także ograniczone bezpieczeństwo długotrwałej terapii, między innymi z powodu wąskiego okna terapeutycznego. Wynikającym z niego głównym działaniem niepożądanym były krwawienia, a zwłaszcza zagrażające życiu krwawienia wewnątrzczaszkowe.

W 2009 roku do terapii wprowadzono nową klase leków stanowiących po raz pierwszy realną alternatywę dla VKA we wskazaniach dotyczących prewencji powikłań zatorowych w niezastawkowym AF oraz terapii pacjentów z zakrzepicą żył głębokich (DVT, deep vein thrombosis) i zatorowością płucną (PE, pulmonary embolism). Doustne leki przeciwzakrzepowe nowej generacji, określane pierwotnie jako NOAC (novel oral anticoagulants), czyli nowe doustne leki przeciwzakrzepowe [1], obecnie są reprezentowane przez cztery substancje, tj. dabigatran, riwaroksaban, apiksaban i edoksaban [2]. Inne skróty stosowane do określenia tej grupy to DOAC (direct oral anticoagulants), TSOAC (target specific oral anticoagulants), a w piśmiennictwie polskim NOAC tłumaczone jako „doustne antykoagulanty niebędące antagonistami witaminy K" [3]. To bogactwo terminologiczne wynika z chęci wyeksponowania odrębności mechanizmu działania nowych leków (bezpośrednie hamowanie trombiny - dabigatran lub aktywnego czynnika X pozostałe 3 leki) od grupy VKA (hamujących pośrednio kilka czynników krzepnięcia - II, VII, IX, X). Autorzy niniejszego opracowania doceniają rozpowszechnienie terminu NOAC w piśmiennictwie i proponują utrzymanie go w polskich publikacjach jako skrótu od non-vitamin K oral anticoagulants, co odzwierciedla ugruntowanie pozycji i zaniknięcie z upływem czasu „elementu nowości” tej grupy leków.

Cztery leki z grupy NOAC wykazują wiele podobieństw - wszystkie zarejestrowano w podobnych wskazaniach (AF oraz spektrum DVT/PE), są stosowane w stałych dawkach ustalanych klinicznie z istotnym uwzględnieniem funkcji nerek, bez konieczności monitorowania siły działania przeciwkrzepliwego. Wszystkie cztery leki poddano bardzo starannej ocenie klinicznej w dużych, podobnie zaprojektowanych badaniach prospektywnych. Pozwalają one jednoznacznie potwierdzić nie tylko większą łatwość efektywnego stosowania NOAC jako antykoagulantu z wyboru, poprawiającego odsetek czasu ze skutecznym efektem przeciwkrzepliwym u pacjenta, ale również jednoznacznie korzystniejsze efekty leczenia. Są one wyrażone utrzymaną lub zwiększoną skutecznością ochrony przed zatorami sercopochodnymi przy jednoczesnym istotnym obniżeniu ryzyka groźnych krwawień, szczególnie wewnątrzczaszkowych, co potwierdzono w dostępnych metaanalizach, sugerując zmniejszenie śmiertelności w porównaniu z terapią VKA [4]. Inne wspólne dla grupy NOAC przewagi to przewidywalny i krótszy niż w przypadku VKA czas działania, znacznie niższe ryzyko interakcji oraz dostępność swoistych antidotów (w chwili przygotowania artykułu: dla dabigatranu - idarucizumab, przewidywany w niedalekiej przyszłości dla antagonistów czynnika Xa - andeksanet alfa). Dzięki tym cechom w najnowszej aktualizacji wytycznych Europejskiego Towarzystwa Kardiologicznego (ESC, European Society of Cardiology), dotyczących leczenia w AF, NOAC mają najwyższą klasę zaleceń w prewencji powikłań zakrzepowo-zatorowych w AF [5]. Należy podkreślić, że NOAC nie zaleca się w AF „zastawkowym” (współcześnie definiowanym jako związane z istotnym hemodynamicznie zwężeniem zastawki mitralnej lub obecnym u pacjentów z protezą zastawki stanowiącą wskazanie do antykoagulacji) $[5,6]$ oraz u pacjentów ze skrajnymi postaciami przewlekłej choroby nerek i wartościami klirensu kreatyniny poniżej 15 (dla dabigatranu 30) ml/kg mc./min. Nie są i prawdopodobnie nie będą przez dłuższy czas dostępne bezpośrednie prospektywne porównania skuteczności i bezpieczeństwa NOAC, dlatego obecnie przyjmuje się ich przewagę terapeutyczną nad VKA jako efekt klasy [7]. W 2016 roku nie ma dowodów przewagi któregokolwiek z leków w obrębie grupy NOAC, choć widoczne są różnice w zakresie efektów poszczególnych dawek [8]. W kluczowych badaniach poszczególnych leków wykazuje się istotne różnice, między innymi dotyczące charakterystyki badanych populacji chorych, co utrudnia bezpośrednie porównywanie ich wyników. Zwięzłe zestawienie podstawowych właściwości NOAC zawarto $w$ tabeli 1.

Należy podkreślić, że stosowanie NOAC diametralnie zmienia nawyki terapeutyczne utrwalone w erze VKA. Wkrótce po aktualizacji zaleceń ESC, wskazującej na pierwszeństwo tych leków w prewencji zatorowości u pacjentów z niezastawkowym AF [9], Europejska Asocjacja Rytmu Serca (EHRA, European Heart Rhythm Association) opublikowała dokumenty ułatwiające praktyczne stosowanie tych leków w różnych kontekstach klinicznych [6]. Celem niniejszego opracowania ekspertów Sekcji Farmakoterapii Sercowo-Naczyniowej Polskiego Towarzystwa Kardiologicznego jest ułatwienie stosowania w polskich realiach leków z grupy NOAC w typowych sytuacjach wymagających specyficznej wiedzy umożliwiającej podejmowanie prawidłowych decyzji terapeutycznych na podstawie danych dostępnych w 2016 roku.

\section{Zapamiętaj!}

Leki przeciwzakrzepowe nowej generacji - NOAC, będące doustnymi antagonistami trombiny lub aktywnego czynnika $X$, stanowią preferowany wybór w zapobieganiu zatorowości sercopochodnej i zakrzepicy żył głębokich/ /zatorowości płucnej.

\section{Wybór leku i nadzorowanie leczenia}

Dzięki unikatowym właściwościom NOAC kwestie praktyczne związane z ich stosowaniem nie są tak istotne jak w przypadku VKA. Po ustaleniu wskazań do antykoagulacji 
Tabela 1. Podstawowe właściwości leków z grupy doustnych antykoagulantów niebędących antagonistami witaminy K (źródła [5, 6])

\begin{tabular}{|c|c|c|c|c|}
\hline Właściwość & $\begin{array}{l}\text { Dabigatran } \\
\text { (antagonista } \\
\text { trombiny) }\end{array}$ & $\begin{array}{c}\text { Riwaroksaban } \\
\text { (antagonista } \\
\text { czynnika Xa) }\end{array}$ & $\begin{array}{l}\text { Apiksaban } \\
\text { (antagonista } \\
\text { czynnika Xa) }\end{array}$ & $\begin{array}{l}\text { Edoksaban } \\
\text { (antagonista } \\
\text { czynnika Xa) }\end{array}$ \\
\hline Biodostępność (\%) & 6 & $\begin{array}{c}66 \\
\text { Podany z posiłkiem: } \\
80-100\end{array}$ & 50 & 62 \\
\hline Czas do maksymalnego stężenia [h] & 3 & $2-4$ & 3 & $1-2$ \\
\hline Okres półtrwania [h] & $12-17$ & $5-13$ & $9-14$ & $10-14$ \\
\hline Dawkowanie [mg] & $2 \times 110-150$ & $1 \times 15-20$ & $2 \times 2,5-5$ & $1 \times 30-60$ \\
\hline Wydalanie przez nerki (\%) & 80 & 33 & 27 & 50 \\
\hline Wiązanie z białkami (\%) & 35 & $92-95$ & 87 & $40-59$ \\
\hline Transportery błonowe & P-gp & $\begin{array}{l}\text { P-gp, białko oporności } \\
\text { raka piersi }\end{array}$ & $\begin{array}{l}\text { P-gp, białko oporności } \\
\text { raka piersi }\end{array}$ & P-gp \\
\hline Metabolizm wątrobowy CYP (\%) & - & 32 & 15 & $<4$ \\
\hline $\begin{array}{l}\text { Kluczowe badania w migotaniu przed- } \\
\text { sionków }\end{array}$ & RE-LY & ROCKET-AF & $\begin{array}{l}\text { ARISTOTLE } \\
\text { AVERROES }\end{array}$ & ENGAGE-AF \\
\hline Minimalny dozwolony $\mathrm{CrCl}[\mathrm{ml} / \mathrm{min}]$ & $\begin{array}{c}30 \\
\text { (W USA } \\
\text { przy CrCl 15-29 } \\
\text { dawka } 2 \times 75 \mathrm{mg})\end{array}$ & 15 & 15 & 15 \\
\hline Cechy szczególne & $\begin{array}{c}\text { Dyspepsja u } 5-10 \% \\
\text { pacjentów }\end{array}$ & $\begin{array}{c}\text { Konieczne podawanie } \\
\text { z posiłkiem }\end{array}$ & - & - \\
\hline
\end{tabular}

(skala $\mathrm{CHA}_{2} \mathrm{DS}_{2}$-VASc) w indywidualnym wyborze konkretnego leku powinno się uwzględnić dane kliniczne, oczekiwane korzyści i ryzyko leczenia. Należy w sposób zrozumiały przedstawić pacjentowi możliwości i aspekty praktyczne leczenia, w tym skuteczność starszych i nowszych leków, przewidywane koszty i konieczność monitorowania międzynarodowego współczynnika znormalizowanego (INR, international normalized ratio) w przypadku VKA. Po dyskusji powinno się uwzględnić preferencje pacjenta. Istnieją skale oceny pozwalające oszacować prawdopodobieństwo niedostatecznej kontroli INR, na przykład SAMe-TT ${ }_{2} \mathrm{R}_{2}$ (uwzględniająca takie dane, jak: płeć, wiek > 60 lat, choroby towarzyszące, stosowane leki, palenie tytoniu, rasę) [10]. Leki z grupy NOAC mogą być stosowane u pacjentów z wadami zastawkowymi (zwężeniem zastawki aortalnej, niedomykalnością aortalną lub mitralną, wadami zastawki trójdzielnej i łagodnym zwężeniem zastawki mitralnej), z istotnym wyjątkiem umiarkowanej/istotnej stenozy mitralnej [11].

Podejmując decyzję o włączeniu NOAC, należy uwzględnić charakterystykę wybranego leku, wiek, masę ciała, funkcję nerek, przebyte epizody krwawienia, przyjmowane jednocześnie inne leki (potencjalne interakcje) i dalszą współprace z pacjentem w procesie leczenia. Należy podkreślić, że stosowanie NOAC nie wymaga rutynowego monitorowania krzepliwości krwi, natomiast ocenę wskaźników krzepnięcia należy rozważyć w sytuacjach wystąpienia poważnych krwawień lub epizodów zakrzepowo-zatorowych w trakcie leczenia. Zalecając konkretny lek, powinno się także rozważyć i przedyskutować z pacjentem kwestię dawkowania NOAC - raz lub 2 razy/dobę. Należy również podać wskazówki dotyczące postępowania w przypadku pominięcia jednej dawki leku. Jeżeli chory ma przyjmować lek co 12 godzin, a od planowanej pory jego zażycia minęło mniej niż 6 godzin, to powinien jeszcze przyjąć pominiętą dawkę. Jeśli natomiast minęło ponad 6 godzin, to pacjent powinien przyjąć kolejną zaplanowaną dawkę. W przypadku leków podawanych raz/dobę opóźnienie wynoszące mniej niż 12 godzin oznacza konieczność przyjęcia pominiętej dawki, natomiast w przypadku opóźnienia ponad 12-godzinnego pacjent powinien przyjąć już kolejną planowaną dawkę. W przypadku zażycia podwójnej dawki leku stosowanego 2 razy/dobę kolejną dawkę się pomija, zaś w sytuacji przyjęcia podwójnej dawki leku stosowanego raz/dobę kolejna dawka powinna być przyjęta zgodnie z planem. W każdym przypadku powinno się też rozważyć zasadność profilaktycznego stosowania inhibitorów pompy protonowej (PPI, proton pump inhibitors). Warunkiem niezbędnym rozpoczęcia leczenia jest znajomość aktualnych wyników badań pacjenta: morfologii krwi (niedokrwistość, 
Tabela 2. Wpływ funkcji nerek na okres półtrwania doustnych antykoagulantów niebędących antagonistami witaminy K (zmodyfikowane wg [6])

\begin{tabular}{lcccc} 
Klirens kreatyniny $[\mathrm{ml} / \mathrm{min}]^{*}$ & \multicolumn{2}{c}{ Okres półtrwania $[\mathrm{h}]$} \\
\hline$>80$ & Dabigatran & Riwaroksaban & Apiksaban & Edoksaban \\
& $12-17$ & $\begin{array}{c}\text { Młodzi: } 5-9 \\
\text { Starsi: } 11-13\end{array}$ & 12 & $10-14$ \\
$50-80$ & $\approx 17$ & $\approx 8,7$ & $\approx 14,6$ & $\approx 8,6$ \\
$30-50$ & $\approx 19$ & $\approx 9,0$ & $\approx 17,6$ & $\approx 9,4$ \\
$15-30$ & $\approx 28$ & $\approx 9,5$ & $\approx 17,3$ & $\approx 16,9$
\end{tabular}

*Brak danych dotyczących pacjentów z klirensem kreatyniny < $15 \mathrm{ml} / \mathrm{min}$

małopłytkowość), stężeń elektrolitów, klirensu i stężenia kreatyniny oraz wartości enzymów wątrobowych. Pacjent powinien otrzymać kartę leczenia przeciwzakrzepowego i powinien informować innych lekarzy o przyjmowaniu leku zmniejszającego krzepliwość krwi. Do standardu opieki należy zaplanowanie wizyty kontrolnej - kontakt z lekarzem powinien nastąpić po miesiącu stosowania leku. Wtedy należy sprawdzić, czy pacjent stosuje się do zaleceń (czy regularnie przyjmuje lek), czy wystąpiły epizody zakrzepowo-zatorowe i epizody krwawień, jakie leki pacjent równocześnie przyjmuje (w tym także te bez recepty), czy wystąpiły jakiekolwiek inne działania niepożądane oraz czy zaistniała potrzeba wykonywania badań krwi i innych badań. Kontrolne badania morfologii krwi i parametrów biochemicznych, szczególnie dotyczących funkcji nerek, powinno się wykonywać co najmniej raz w roku (przy obniżonym klirensie kreatyniny [ $\mathrm{CrCl}$, creatinine clearance] proponuje się wyznaczanie kontroli po upływie liczby miesięcy odpowiadającej wartości $\mathrm{CrCl}$ w [ml/min] podzielonej przez 10) (patrz także tab. 2) [6].

\section{Praktyczne uwagi dotyczące dawkowania} NOAC u chorych z przewlekłą chorobą nerek Obniżona filtracja kłębuszkowa (GFR, glomerular filtration rate) wpływa na stężenie NOAC i stanowi ważny aspekt kwalifikacji do leczenia i jego kontroli. Poszczególne leki różnią się stopniem wydalania przez nerki (patrz tab. 1); pacjenci z obniżonym $\mathrm{CrCl}$ wymagają dostosowania dawek według reguł swoistych dla danego leku.

W odniesieniu do dabigatranu eliminacja nerkowa jest najwyższa w obrębie klasy i wynosi średnio $80 \%$ - przy CrCL 30-49 ml/min dawkowanie 2 razy $150 \mathrm{mg} /$ dobę jest dopuszczalne, ale należy rozważyć podawanie dawki 2 razy 110 mg przy uwzględnieniu ryzyka krwawień według skali HAS-BLED. W Stanach Zjednoczonych, lecz nie w Europie, dostępna jest dawka 2 razy $75 \mathrm{mg}$ dla chorych z $\mathrm{CrCl}$ 15-29 $\mathrm{ml} / \mathrm{min}$.

W przypadku riwaroksabanu typowa dawka leku wynosi $20 \mathrm{mg}$ z posiłkiem (optymalnie wieczornym), a mniejszą dawkę (15 mg) należy zastosować u chorych z CrCl 15-49 $\mathrm{ml} / \mathrm{min}$. Z kolei w przypadku apiksabanu typowa dawka to 2 razy $5 \mathrm{mg} /$ dobę i jest zmniejszana do 2 razy
2,5 mg, gdy $\mathrm{CrCl}$ wynosi $15-29 \mathrm{ml} / \mathrm{min}$ lub gdy występują dwie z trzech sytuacji klinicznych: wiek 80 lat lub więcej, masa ciała mniejsza lub równa $60 \mathrm{~kg}$, stężenie kreatyniny większe lub równe $1,5 \mathrm{mg} / \mathrm{dl}$. Dawkę edoksabanu $60 \mathrm{mg}$ raz/dobę należy stosować u pacjentów z CrCl 50-95 ml/min. W przypadku klirensu $15-50 \mathrm{ml} / \mathrm{min}$ należy zastosować mniejszą dawkę - $30 \mathrm{mg}$. U pacjentów w wieku powyżej 75 lat zaleca się częstsze kontrole funkcji nerek, co najmniej raz na 6 miesięcy. $U$ chorych dializowanych, ze względu na brak odnośnych badań, zaleca się VKA [6, 12].

Ogólnie mniejsze dawki NOAC powinny być rozważane u pacjentów z upośledzoną funkcją nerek (jak wyżej), w wieku powyżej 75-80 lat, z małą masą ciała (<60 kg), leczonych dodatkowo lekiem przeciwpłytkowym, z małopłytkowością lub epizodami krwawień po większych dawkach NOAC $[6,13]$.

\section{Interakcje NOAC z innymi lekami}

Wiedza na temat potencjalnych interakcji NOAC z innymi lekami stale się pogłębia. Interakcje farmakodynamiczne dotyczą głównie stosowania NOAC łącznie z lekami przeciwpłytkowymi (kwas acetylosalicylowy, klopidogrel, prasugrel i tikagrelor) oraz niesteroidowymi lekami przeciwzapalnymi (NLPZ). Ryzyko krwawień przy terapii skojarzonej może wzrastać do 60\%, dlatego zaleca się skracanie do niezbędnego minimum czasu leczenia NOAC i 1-2 lekami przeciwpłytkowymi. W sytuacjach wymagających terapii skojarzonej jest zalecane stosowanie klopidogrelu i mniejszych dostępnych dawek NOAC oraz unikanie leczenia skojarzonego NOAC i prasugrelem lub tikagrelorem.

Interakcje farmakokinetyczne dotyczą kompetycji w zakresie eliminacji NOAC i innych leków z organizmu oraz powinowactwa do białek błonowych glikoproteiny P (P-gp, P-glycoprotein) (transporterów błonowych). Eliminacja w wątrobie zachodzi przy udziale enzymów cytochromu CYP450, a interakcje mogą wystąpić na zasadzie inhibicji lub indukcji tych enzymów, co wpływa na stężenia leków w surowicy i siłę ich działania. W tabeli 3 przedstawiono poznane interakcje farmakokinetyczne NOAC - w większości przypadków dotyczą one starszych, dobrze przebadanych leków, na szczęście obecnie rzadziej stosowanych, które mogą być zastąpione innymi preparatami. Do rozważenia 
Tabela 3. Istotne klinicznie interakcje farmakokinetyczne doustnych antykoagulantów niebędących antagonistami witaminy K (NOAC, non-vitamin K oral anticoagulants) z innymi lekami (źródła [6, 13])

\begin{tabular}{|c|c|c|c|c|c|}
\hline \multirow[t]{2}{*}{ Lek } & \multirow[t]{2}{*}{ Mechanizm } & \multicolumn{4}{|c|}{ NOAC } \\
\hline & & Dabigatran & Riwaroksaban & Apiksaban & Edoksaban \\
\hline Karbamazepina & Indukcja CYP3a4, P-gp & Unikać & Unikać & Unikać & Bez zaleceń \\
\hline Klaritromycyna & Inhibicja CYP3a4, P-gp & Bez zmian & Bez zmian & $\begin{array}{c}\text { Zmniejszenie } \\
\text { dawki }\end{array}$ & Bez zaleceń \\
\hline Rifampicyna & Inhibicja CYP3a4, P-gp & Unikać & Unikać & Unikać & Unikać \\
\hline Ritonawir & Inhibicja CYP3a4, P-gp & Bez zmian & Unikać & $\begin{array}{c}\text { Zmniejszenie } \\
\text { dawki }\end{array}$ & Bez zaleceń \\
\hline Itrakonazol & Inhibicja CYP3a4, P-gp & Bez zmian & Unikać & $\begin{array}{c}\text { Zmniejszenie } \\
\text { dawki }\end{array}$ & Bez zaleceń \\
\hline Ketokonazol & Inhibicja CYP3a4, P-gp & $\begin{array}{c}\mathrm{CrCl} 30-50 \mathrm{ml} / \\
\min 2 \times 75 \mathrm{mg}\end{array}$ & Unikać & $\begin{array}{c}\text { Zmniejszenie } \\
\text { dawki }\end{array}$ & Bez zaleceń \\
\hline Fenytoina & Indukcja CYP3a4, P-gp & Unikać & Unikać & Unikać & Bez zaleceń \\
\hline Dronedaron & Inhibicja P-gp & $\begin{array}{c}\mathrm{CrCl} 30-50 \mathrm{ml} / \\
\min 2 \times 75 \mathrm{mg}\end{array}$ & Bez zaleceń & Bez zaleceń & Bez zmiany dawki \\
\hline Amiodaron & Kompetycja P-gp & $\begin{array}{c}\text { Zmniejszenie } \\
\text { dawki }\end{array}$ & $\begin{array}{c}\text { Zmniejszenie } \\
\text { dawki }\end{array}$ & Brak danych & $\begin{array}{c}\text { Zmniejszenie } \\
\text { dawki }\end{array}$ \\
\hline Werapamil & Inhibicja CYP3a4, P-gp & $\begin{array}{c}\text { Zmniejszenie } \\
\text { dawki }\end{array}$ & $\begin{array}{c}\text { Zmniejszenie } \\
\text { dawki }\end{array}$ & Brak danych & $\begin{array}{c}\text { Zmniejszenie } \\
\text { dawki }\end{array}$ \\
\hline Diltiazem & Inhibicja CYP3a4, P-gp & Bez zmian & $\begin{array}{c}\text { Zmniejszenie } \\
\text { dawki }\end{array}$ & $\begin{array}{c}\text { Zmniejszenie } \\
\text { dawki }\end{array}$ & Brak danych \\
\hline Atorwastatyna & Inhibicja CYP3a4, P-gp & Słaby wpływ & Bez zmian & Brak danych & Bez zmian \\
\hline
\end{tabular}

P-gp (P-gllycoprotein) - glikoproteina P; $\mathrm{CrCl}$ (creatinine clearance) - klirens kreatyniny

pozostaje także kwestia stosowanych dawek, które obecnie często są mniejsze (werapamil, amiodaron, diltiazem) niż w przeszłości $[6,13]$. Jak dotąd nie ma danych na temat możliwych interakcji NOAC z preparatami ziołowymi, suplementami diety czy innymi substancjami leczniczymi dostępnymi bez recepty.

\section{Zapamiętaj!}

Doustne antykoagulanty nowej generacji zwiększają skuteczność i bezpieczeństwo leczenia przeciwzakrzepowego, po uwzględnieniu właściwości konkretnego leku, wieku i funkcji nerek pacjenta oraz możliwych interakcji z innymi lekami. Zaleca się jest regularne monitorowanie $\mathrm{CrCl}$.

\section{Monitorowanie parametrów krzepnięcia}

Zgodnie z charakterystykami produktów leczniczych stosowanie NOAC nie wymaga rutynowego monitorowania parametrów krzepnięcia krwi. Jednak w pewnych sytuacjach klinicznych, na przykład u pacjentów z masywnym krwawieniem lub krwawieniem zagrażającym życiu, w przypadku pilnego zabiegu chirurgicznego lub procedury inwazyjnej, przedawkowania leku lub nawrotów epizodów zakrzepowo-zatorowych, określenie aktualnego poziomu antykoagulacji może być niezbędne, by dokonać wyboru optymalnej strategii postępowania [14].
Obecnie nie ma powszechnie dostępnej, wystandaryzowanej laboratoryjnej metody monitorowania antykoagulacyjnego efektu dabigatranu [15], riwaroksabanu [16, 17] i apiksabanu. U każdego pacjenta przed włączeniem NOAC należy ocenić morfologię krwi, funkcję nerek (CrCl) oraz funkcję wątroby (aktywność aminotransferaz). Trzeba również oszacować ryzyko krwawienia (z identyfikacją czynników modyfikowalnych i niemodyfikowalnych) [5] za pomocą dostępnych skal (np. HAS-BLED lub ABC [age, biomarkers, clinical history]) oraz wykluczyć, na podstawie wywiadu lekarskiego, wrodzone bądź nabyte zaburzenia krzepnięcia. W razie potrzeby wynikającej z oceny klinicznej, w nielicznych przypadkach, należy dodatkowo określić podstawowe parametry hemostazy - czas częściowej tromboplastyny po aktywacji (APTT, activated partial thromboplastin time) i PT oraz rozważyć oznaczenie stężenia fibrynogenu i/lub czasu trombinowego (TT, thrombin time).

\section{Monitorowanie laboratoryjne leczenia dabigatranem}

Leczenie dabigatranem wpływa na APTT, lecz jego zmiana zależy od czułości użytego aktywatora i typu koagulometru. W przypadku przewlekłego stosowania dabigatranu w dawce $150 \mathrm{mg}$ co 12 godzin APTT ulega istotnemu (1,5-3-krotnemu) wydłużeniu, ale stopień tego wydłużenia nie koreluje ściśle ze stężeniem dabigatranu w osoczu, 
zatem APTT nie nadaje się do precyzyjnego określenia stopnia antykoagulacji. Wydłużenie APTT przekraczające 65-80 s bezpośrednio przed kolejną dawką leku może wskazywać na nadmierne obniżenie krzepliwości. Wartości APTT i TT mieszczące się w granicach normy wskazują na brak antykoagulacyjnego efektu dabigatranu. Wartość poszczególnych testów u pacjentów leczonych dabigatranem jest następująca:

- PT - mniej czuły na przeciwkrzepliwe działanie dabigatranu niż APTT; jego wydłużenie jest zmienne, dlatego nie zaleca się go do monitorowania siły działania dabigatranu; orientacyjna metoda oceny działania przeciwkrzepliwego riwaroksabanu;

- TT - bardzo czuły na aktywność antykoagulacyjną dabigatranu, gdyż już przy małych stężeniach tego leku staje się nieoznaczalny i dlatego nie nadaje się do precyzyjnego monitorowania jego efektu przeciwkrzepliwego;

- rozcieńczony czas trombinowy (dTT, diluted thrombin time $=$ test Hemoclot $^{\circledR}$ ) - pozwala na ilościowy pomiar stężenia dabigatranu w osoczu (wynik wyrażony w [s] lub [ng/ml]); metodę Hemoclot ${ }^{\circledR}$ zaakceptowano do użytku klinicznego w Europie jako zalecaną do monitorowania siły działania dabigatranu $[18,19]$;

- ekarynowy czas krzepnięcia (ECT, ecarin clotting time) - pozwala na ilościowy pomiar stężenia dabigatranu w osoczu (wynik wyrażony w [s] ulega 2-4-krotnemu wydłużeniu u pacjentów stosujących przewlekle dabigatran w dawce $150 \mathrm{mg}$ co $12 \mathrm{~h}$ ); test zaleca się do monitorowania siły działania dabigatranu;

- przedłużony aktywowany czas krzepnięcia (ACT, activated clotting time) oznaczany metodą szybkiej tromboelastografii - może być stosowany do orientacyjnej oceny działania dabigatranu i oceny ryzyka krwawień u pacjentów przyjmujących dabigatran i hospitalizowanych z powodu poważnych urazów [15].

\section{Monitorowanie laboratoryjne leczenia riwaroksabanem}

Mierzone bezpośrednio po podaniu riwaroksabanu (zwłaszcza w większych dawkach) APTT oraz PT ulegają wydłużeniu, ale efekt jest na tyle zmienny, że oznaczania tych parametrów nie zaleca się do monitorowania siły działania riwaroksabanu. Istotny wpływ na wynik pomiaru PT ma rodzaj zastosowanej tromboplastyny. Stężenie fibrynogenu ani TT nie zmieniają się pod wpływem riwaroksabanu.

Najlepszym sposobem precyzyjnego monitorowania antykoagulacyjnego działania riwaroksabanu jest pomiar aktywności anty-Xa [17, 18]. Trwają prace nad standaryzacją i walidacją tego testu w omawianym wskazaniu.

\section{Monitorowanie laboratoryjne leczenia apiksabanem}

Apiksaban wydłuża APTT i PT, brakuje jednak ścisłej korelacji tych parametrów z dawką i dlatego testy te nie są zalecane do monitorowania siły działania apiksabanu. Brakuje danych o wpływie apiksabanu na wynik TT.

Podobnie jak w odniesieniu do riwaroksabanu pomiar aktywności anty-Xa jest najlepszym sposobem precyzyjnego monitorowania antykoagulacyjnego działania apiksabanu. Trwają prace nad standaryzacją i walidacją tego testu w omawianym wskazaniu.

\section{Monitorowanie działania dabigatranu, riwaroksabanu i apiksabanu}

Podsumowanie monitorowania działania dabigatranu, riwaroksabanu i apiksabanu przedstawiono w tabeli 4.

Tabela 4. Parametry krzepliwości krwi a doustne antykoagulanty

\begin{tabular}{|c|c|c|}
\hline Test & Dabigatran & Riwaroksaban, apiksaban \\
\hline PT & Nie można stosować & † w sposób zależny od dawki (średnio 16-25 s) \\
\hline INR & Nie można stosować & Nie można stosować \\
\hline APTT & $\uparrow$ średnio 40-60 s & † w sposób zależny od dawki (średnio do 48 s) \\
\hline TT & $\uparrow-$ wynik często nieoznaczalny & Norma \\
\hline Fibrynogen & $\downarrow$ lub norma & Norma \\
\hline dTT & $\begin{array}{l}\text { Zalecany do monitorowania - wynik > } 65 \text { s } \\
\text { lub > } 200 \text { ng/ml sugeruje wzrost ryzyka krwawień }\end{array}$ & Nie można stosować \\
\hline ECT & $\begin{array}{l}\text { Zalecany do monitorowania } \\
\uparrow \text { średnio 2-4-krotnie }\end{array}$ & Nie dotyczy \\
\hline Hemoclot $^{\circledR}$ & $\begin{array}{l}\uparrow \text { w sposób zależny od dawki } \\
\text { Zalecany do monitorowania }\end{array}$ & Nie dotyczy \\
\hline Aktywność anty-Xa & Brak zastosowania & Zalecana do monitorowania \\
\hline
\end{tabular}




\section{Zapamiętaj!}

Stosowanie doustnych bezpośrednich inhibitorów Ila iXa nie wymaga rutynowego monitorowania parametrów krzepnięcia krwi. Testami ilościowymi w ocenie stężenia dabigatranu są dTT (Hemoclot ${ }^{\circledR}$ ) i ECT, a w odniesieniu do riwaroksabanu i apiksabanu - pomiar aktywności anty-Xa.

\section{Konwersja z VKA na NOAC}

Istnieją sytuacje, niekoniecznie związane ze stanem klinicznym pacjenta, czasem dyktowane kwestiami ekonomicznymi, w których pacjent i lekarz stają przed koniecznością zamiany stosowanego dotychczas schematu leczenia przeciwzakrzepowego. Zamiana ta może dotyczyć zaprzestania stosowania VKA i wdrożenia do leczenia jednego z NOAC lub postępowania odwrotnego - zastąpienia NOAC przez VKA. Niezależnie od wskazania uzasadniającego stosowanie przewlekłej terapii przeciwzakrzepowej konwersja grup leków wymaga ostrożności i znajomości podstawowych mechanizmów farmakodynamicznych, a także właściwości farmakokinetycznych stosowanych cząsteczek.

Kluczowym aspektem konwersji terapii przeciwzakrzepowej w obie strony, tj. z leków nowych na stare oraz z leków „starych" na nowe, jest zachowanie skuteczności leczenia (wystarczającego efektu przeciwkrzepliwego) przy jedoczesnej minimalizacji ryzyka powikłań krwotocznych (unikanie nakładania działania przeciwzakrzepowego różnych leków). W przypadku rezygnacji ze „starych” leków przeciwzakrzepowych (acenokumarol, warfaryna) oraz decyzji o wdrożeniu jednego z nowych doustnych leków przeciwzakrzepowych obowiązują następujące zasady ogólne:

- kontrolne oznaczenie INR należy wykonać 2 dni po odstawieniu acenokumarolu oraz 3 dni po odstawieniu warfaryny;

- terapię NOAC można rozpocząć niezwłocznie, gdy INR wynosi poniżej 2,0;

- jeśli INR wynosi 2,0-2,5, to sugeruje się, aby pierwszą dawkę NOAC podać następnego dnia po wykonanym badaniu INR (ale dopuszczalne jest również podanie nowego leku tego samego dnia);

- jeśli INR przekracza 3,0, to zaleca się odroczenie włączenia NOAC na czas zależny od rodzaju stosowanego wcześniej leku. Okres półtrwania acenokumarolu wynosi 8-14 godzin, natomiast warfaryny - 36-42 godzin. W związku z powyższym kolejne kontrolne badanie INR należy wykonać po kolejnych 24 godzinach w przypadku pacjentów stosujących wcześniej acenokumarol oraz po kolejnych 48 godzinach u pacjentów stosujących wcześniej warfarynę.

W aktualnych wytycznych EHRA dotyczących zastosowania NOAC sugeruje się opisaną wyżej, ujednoliconą zasadę wprowadzenia nowych leków przeciwzakrzepowych. Alternatywne podejście jest zróżnicowane w zależności od wprowadzanej do leczenia cząsteczki. Podstawą tego zróżnicowania są właściwości farmakokinetyczne poszczególnych cząsteczek, a dokładne instrukcje zawarto w charakterystykach poszczególnych produktów leczniczych. Według tych dokumentów NOAC można wdrożyć przy INR:

- mniejszym lub równym 3 dla riwaroksabanu;

- mniejszym lub równym 2,5 dla edoksabanu;

- mniejszym lub równym 2 dla dabigatranu i apiksabanu. Warto zauważyć, że jeżeli pierwsze oznaczenie INR po odstawieniu VKA wynosi 2-2,5, to za wcześniejszym wdrożeniem NOAC (bez kolejnej kontroli INR) przemawia wysokie ryzyko powikłań zakrzepowo-zatorowych ( $\geq 3$ pkt. w $\mathrm{CHA}_{2} \mathrm{DS}_{2}$-VASc). Natomiast za odroczeniem rozpoczęcia nowego schematu leczenia, zarówno przy INR 2-2,5, jak i INR ponad 3, przemawia wysokie ryzyko powikłań krwotocznych ( $\geq 3$ pkt. w HAS-BLED) [6]. W tym kontekście warto zaznaczyć, że w przypadku wysokiego ryzyka powikłań zakrzepowo-zatorowych i pierwszego po odstawieniu „starych” leków kontrolnego INR ponad 3 lekiem nowej generacji, który można zastosować najszybciej, będzie riwaroksaban (już przy kolejnym oznaczeniu INR $\leq 3$ ). W przypadku leków przeciwzakrzepowych podawanych parenteralnie konwersja do przewlekłej terapii z zastosowaniem NOAC jest znacznie mniej skomplikowana:

- dowolny lek z grupy NOAC można podać w zasadzie bezpośrednio po zaprzestaniu stałego wlewu heparyny niefrakcjonowanej (jej okres półtrwania wynosi ok. $2 \mathrm{~h}$, ulega wydłużeniu u pacjentów z zaawansowaną chorobą nerek);

- w przypadku stosowania heparyny drobnocząsteczkowej pierwszą dawkę NOAC należy podać w miejsce kolejnej przewidywanej dawki heparyny. Wyżej opisana zasada obowiązuje również w przypadku zamiany terapii NOAC na terapię parenteralną.

W przypadku zamiany między cząsteczkami z grupy NOAC pierwszą dawkę nowej cząsteczki podaje się w terminie przewidzianym dla kolejnej dawki poprzednio stosowanego leku. Potencjalnie najbardziej skomplikowanym procesem jest zamiana terapii z zastosowaniem NOAC na VKA. Zabieg ten wymaga przejściowo jednoczesnego stosowania leków nowej i „starej” generacji. Po 2-3 dniach od wdrożenia acenokumarolu lub warfaryny zaleca się kontrolę INR - w przypadku wartości powyżej 2 można odstawić stosowany wcześniej NOAC, jednak terapeutyczną wartość INR należy potwierdzić po kolejnych 24 godzinach. Jeśli w pierwszym kontrolnym oznaczeniu INR nie przekroczy 2, to nadal trzeba stosować oba leki, a kolejną kontrolę przeprowadzić w ciągu 1-3 dni. Leki z grupy NOAC będące inhibitorami czynnika Xa wpływają na wartości INR. Należy więc przyjąć ogólną zasadę, że kontrolę INR wykonuje się przed przyjęciem kolejnej dawki NOAC [6]. W przypadku edoksabanu w trakcie fazy przejściowej, przy jednoczesnym 
stosowaniu VKA, zaleca się podawanie połowy dawki terapeutycznej. Podobnego schematu nie oceniano jednak w odniesieniu do pozostałych NOAC.

Mimo dość jasno określonych zasad zamiany antykoagulantów, codzienna praktyka często odbiega od zaleceń. Dowodzą tego między innymi dane z Dresden NOAC Registry [20]. Jednym z celów tego rejestru była ocena bezpieczeństwa konwersji z antykoagulantów VKA do NOAC. Do badania włączono w sumie 2231 pacjentów, spośród których u 716 dokonano omawianej w tym paragrafie konwersji. Jedynie u 75,1\% spośród tej grupy w ciągu 10 dni poprzedzających zamianę lub po zamianie grupy leków przeciwzakrzepowych oznaczono INR. U pacjentów, u których oznaczono INR, jego średnia wartość wynosiła 2,4 . Autorzy rejestru zaobserwowali również, że NOAC włączano zwykle 2-5 dni po odstawieniu warfaryny lub acenokumarolu. Zaobserwowane postępowanie miało więc często charakter intuicyjny, bez odniesienia do kontrolnych oznaczeń INR. Co ciekawe, kontrola INR według wytycznych nie zmieniała ryzyka powikłań krwotocznych oraz incydentów sercowo-naczyniowych (ogólne ryzyko ciężkich krwawień w badanej populacji wynosiło 0,3\%, a incydentów sercowo-naczyniowych - 0,8\% po 30 dniach obserwacji). Warto również przypomnieć o istnieniu danych sugerujących, że stosowanie nowych leków przeciwzakrzepowych zamiast warfaryny w populacji pacjentów z niezastawkowym AF jest postępowaniem efektywnym kosztowo, co stanowi ekonomiczny argument za częstszą konwersją schematów leczenia na nowsze [21].

\section{Zapamiętaj!}

Przy zmianie rodzaju leku przeciwzakrzepowego (VKA/ /NOAC) kluczowe znaczenie mają zachowanie skuteczności leczenia i minimalizacja ryzyka powikłań krwotocznych zgodnie ze schematami kontroli wynikającymi z farmakokinetyki leków.

\section{Postępowanie w przypadku krwawień u pacjenta leczonego NOAC}

U pacjentów otrzymujących leki przeciwzakrzepowe mogą się zdarzać krwawienia, nawet przy zachowaniu zasad bezpieczeństwa takiej terapii. Częstość dużych krwawień u chorych w trakcie terapii VKA i NOAC ocenia się na 2,1-3,6\%/rok. Krwawienia kończące się zgonem dotyczą 0,5\% osób leczonych NOAC rocznie. Małe krwawienia moga zwiastować krwawienia duże, a duże krwawienia prowadzą do zwiększonej śmiertelności (30-dniowa śmiertelność w grupie osób po dużym krwawieniu wynosi 9-13\%). U pacjentów leczonych NOAC bardzo ważną rolę odgrywają dostosowanie dawki leku do funkcji nerek, a także, podobnie jak u chorych leczonych VKA, unikanie nieuzasadnionego kojarzenia z lekami przeciwpłytkowymi i NLPZ. Definicje „dużych krwawień”, innych klinicznie istotnych krwawień oraz „małych krwawień” przedstawiono poniżej [22].

\section{Duże krwawienia:}

- krwawienia do ważnych dla życia organów: ośrodkowego układu nerwowego, (wewnątrzczaszkowe i podtwardówkowe), wewnątrzgałkowe, do worka osierdziowego, do przestrzeni pozaotrzewnowej, dostawowe i wewnątrzmięśniowe z wywołaniem zespołu ciasnoty przedziałów powięziowych;

- klinicznie jawne krwawienia ze zmniejszeniem stężenia hemoglobiny przynajmniej o $2 \mathrm{~g} / \mathrm{dl}$;

- wymagające interwencji chirurgicznej;

- wymagające dożylnego podania substancji presyjnych. Klinicznie istotne (umiarkowanie intensywne) krwawienia to krwawienia niespełniające kryteriów dużego krwawienia, ale wymagające:

- hospitalizacji albo wzmożonego nadzoru medycznego;

- natychmiastowej interwencji lekarskiej;

- zmiany dotychczasowej terapii przeciwzakrzepowej. Małe krwawienia:

- ustępujące samoistnie;

- niewymagające interwencji/konsultacji lekarskiej;

- niewymagające hospitalizacji.

\section{Ogólne zasady postępowania}

przy krwawieniach u chorego przyjmującego NOAC

Ze względu na krótki okres działania NOAC w przypadku niewielkich krwawień przeczekanie, tj. wybór opcji naturalnej eliminacji leku, może być korzystniejszy niż intensywne metody leczenia. Po zaprzestaniu terapii NOAC powrotu prawidłowej hemostazy należy oczekiwać po 12-24 godzinach od podania ostatniej dawki antykoagulantu, ponieważ okres półtrwania każdego z tych leków wynosi około 12 godzin, a w przypadku pacjentów przyjmujących dabigatran zależy od funkcji nerek. Przewaga NOAC nad VKA wynikająca z braku konieczności monitorowania stężenia leków i ich działania przeciwkrzepliwego w przypadku krwawienia nie stanowi zalety. Błyskawiczna ocena podstawowych parametrów układu hemostazy, takich jak APTT, TT i PT, pozwala na orientacyjną jakościową ocenę, czy chory pozostaje pod wpływem działania leku (APTT i TT u chorych przyjmujących dabigatran, PT u chorych przyjmujących riwaroksaban) i może sugerować, że krwawienie nie wiąże się bezpośrednio z prowadzoną terapią przeciwzakrzepową. Parametry hemostazy zawsze należy odnosić do okresu, który upłynął od ostatniej przyjętej dawki leku ze względu na szybkie zmiany stężenia leku w osoczu i krótki okres półtrwania NOAC. W celu pomiaru ilościowego aktywności dabigatranu zaleca się oznaczanie ECT lub ocenę za pomocą testu Hemoclot ${ }^{\circledR}$ (dTT), a w celu oceny ilościowej działania inhibitorów czynnika krzepnię- 
cia Xa - testy chromogenne anty-Xa. Jednak nie są to oznaczenia powszechnie dostępne. Należy pamiętać, że zastosowanie witaminy $\mathrm{K}$, protaminy ani świeżo mrożonego osocza, użytecznych przy krwawieniach spowodowanych VKA i heparyną, jest całkowicie nieskuteczne w przypadku NOAC. Koncentraty czynników zespołu protrombiny (PCC, prothrombin complex concentrate) - czteroskładnikowy (zawierający czynniki II, VII, IX i X) lub trójskładnikowy (czynniki II, IX i X) - do czasu zarejestrowania swoistego czynnika odwracającego działanie dabigatranu stanowiły najlepszą opcję postępowania w przypadku dużych i zagrażających życiu krwawień. Podanie aktywowanego koncentratu czynników zespołu protrombiny (aPCC, activated prothrombin complex concentrate) (Feiba ${ }^{\circledR}$ ) powinno być rozważane, jeżeli jest natychmiastowo dostępny.

Strategie leczenia krwawień u pacjentów przyjmujących dabigatran zmieniła rejestracja 20 listopada 2015 roku swoistego antidotum - idarucizumabu (Praxbind ${ }^{\circledR}$, Boehringer Ingelheim), stanowiącego fragment humanizowanego monoklonalnego przeciwciała natychmiast unieczynniającego przyjęty uprzednio dabigatran (po podaniu dożylnym w 2 dawkach po 2,5 g w odstępie < $15 \mathrm{~min}$ ). Badanie REVERSE-AD ( $A$ Study of Reversal Effects of Idarucizumab on Active Dabigatran) [23] nad idarucizumabem w grupie pacjentów leczonych dabigatranem, u których wystąpiło krwawienie zagrażające życiu lub zachodzi konieczność pilnej operacji, trwa, lecz korzystne wyniki pozwoliły na przeprowadzenie procesu rejestracji antidotum dla dabigatranu przed ukończeniem badania. W III fazie badań klinicznych znajduje się andeksanet alfa (PRT 064445, Portola $^{\circledR}$ ) [24], będący rekombinowanym białkiem - zmodyfikowaną cząsteczką czynnika Xa z mutacją w miejscu katalitycznym, odwracającym działanie bezpośrednich inhibitorów czynnika Xa, jak również heparyn drobnocząsteczkowych i fondaparinuxu. Badaniom poddawana jest również aripazina (ciraparantag, PER 997, Perosphere ${ }^{\circledR}$ ) [25] - syntetyczna mała molekuła wiążąca się z antykoagulantem, uniwersalne antidotum dla inhibitorów czynnika Xa, II, heparyn i fondaparinuxu.

Powtórne wdrożenie terapii przeciwzakrzepowej po epizodzie poważnego krwawienia oraz decyzja o czasie powrotu do takiej terapii zależą od identyfikacji miejsca krwawienia i wdrożonej terapii zapobiegającej krwawieniu. Rozważenia wymaga wówczas zamiana NOAC (w przypadku krwawienia z przewodu pokarmowego - z riwaroksabanu lub dabigatranu na apiksaban lub VKA), zmniejszenie dawki lub modyfikacja terapii towarzyszącej. Podsumowanie zasad postępowania w przypadku krwawieniu u pacjenta leczonego NOAC zawarto w tabeli 5.

\section{Zapamiętaj!}

Kluczowe znaczenie dla opanowania krwawienia u pacjenta leczonego NOAC, przy ograniczonych możliwościach rutynowej oceny siły działania przeciwkrzepliwego, mają pełna ocena kliniczna, identyfikacja podłoża krwawienia, oszacowanie czasu niezbędnego dla eliminacji leku, próba wyrównania niedoborów czynników układu krzepnięcia, a w przypadku ciężkiego krwawienia u pacjenta leczonego dabigatranem - dializa lub podanie swoistego antidotum (idarucizumabu).

\section{Stosowanie NOAC a przygotowanie pacjenta do kardiowersji}

Jednym z podstawowych celów stosowania doustnych antykoagulantów jest obniżenie ryzyka powikłań zatorowych przy przywracaniu rytmu zatokowego metodą kardiowersji elektrycznej lub farmakologicznej. Ryzyko zatorowości przy kardiowersji bez antykoagulacji ocenia się na 5-7\%, a standardem postępowania stało się przygotowanie lekami przeciwzakrzepowymi, zapewniające spadek ryzyka do około 0,5\% (strategii tej nie oceniano w badaniach kontrolowanych). W wytycznych z 2012 roku [9] zaleca się wykazanie przynajmniej 3-tygodniowego okresu prawidłowej antykoagulacji z użyciem dabigatranu lub VKA przy INR przekraczającym 2 (co w praktyce sprowadza się zwykle do 2 terapeutycznych wyników INR w odstępie $\geq 21$ dni); alternatywnie przygotowanie może polegać na wykluczeniu skrzepliny w echokardiograficznym badaniu przezprzełykowym (TEE, transesophageal echocardiography). Strategia wykorzystująca obrazowanie umożliwia rezygnację z fazy leczenia przeciwzakrzepowego poprzedzającej kardiowersję. Przygotowanie do kardiowersji nie jest konieczne, jeżeli AF trwa krócej niż 48 godzin lub jeśli pacjent był przewlekle leczony przeciwzakrzepowo. W każdym przypadku konieczne jest jednak minimum 4-tygodniowe leczenie przeciwzakrzepowe po umiarowieniu.

Ponieważ w przypadku stosowania NOAC nie wykorzystuje się monitorowania siły działania leku, to potwierdzenie efektu leczniczego sprowadza się wyłącznie do zebrania wywiadu potwierdzającego regularne stosowanie leku bez pominięć dawek, co ma istotniejsze znaczenie niż w przypadku VKA - wskutek krótszego czasu działania leków nowej generacji. Niekiedy stosuje się procedury pisemnego poświadczenia przez pacjenta lub zliczanie wykorzystanych tabletek. W przypadkach wątpliwych możliwa jest konwersja do strategii opartej na wykluczeniu skrzepliny w TEE. 
Tabela 5. Zasady postępowania w przypadku krwawienia u pacjenta leczonego doustnym antykoagulantem niebędącym antagonistą witaminy K (NOAC, non-vitamin K oral anticoagulant)

Krwawienia podczas stosowania NOAC - ogólne zasady postępowania

Określić czas przyjęcia ostatniej dawki NOAC, rozważyć podanie węgla aktywowanego, jeżeli NOAC został przyjęty nie później niż przed 3-4 h

Ustalić okres od początku krwawienia, podjąć próbę określenia objętości utraconej krwi, ocenić, czy krwawienie pozostaje aktywne Ocenić, czy chory nie przyjmował ASA, inhibitorów $\mathrm{P}_{2} \mathrm{Y}_{12}, \mathrm{NLPZ}$, inhibitorów P-gp, inhibitorów CYP3A4

Zlecić badanie podstawowych parametrów układu hemostazy (Ht, Er, liczbę płytek krwi, PT, TT, APTT) oraz funkcji nerek (CrCl)

Zidentyfikować miejsce krwawienia

Ocenić współistniejące schorzenia, stan układu krążenia

\begin{tabular}{|c|c|c|}
\hline Niewielkie krwawienia & Umiarkowanie intensywne krwawienia & Krwawienie zagrażające życiu \\
\hline $\begin{array}{l}\text { Wydłużenie czasu do przyjęcia } \\
\text { kolejnej dawki leku lub jej pomi- } \\
\text { nięcie } \\
\text { Kontrola innych leków przyjmowa- } \\
\text { nych przez pacjenta: } \\
\text { - } \quad \text { ASA } \\
\text { - inhibitorów } P_{2} Y_{12} \\
\text { - } \quad \text { NLPZ } \\
\text { - inhibitorów P-gp } \\
\text { - inhibitorów CYP3A4 }\end{array}$ & $\begin{array}{l}\text { Terapia wspomagająca: } \\
\text { - } \quad \text { ucisk mechaniczny } \\
\text { - } \text { hemostaza chirurgiczna, hemostaza endoskopowa } \\
\text { jeśli krwawienie z przewodu pokarmowego } \\
\text { - } \quad \text { płynoterapia (jeśli wskazane koloidy), świeżo mro- } \\
\text { żone osocze (jedynie w celu zwiększenia objętości } \\
\text { osocza) } \\
\text { - } \quad \text { kkcz, jeśli wskazany (rozważyć przy zmniejszeniu } \\
\text { stężenia Hb } 7-8 \mathrm{~g} / \mathrm{dl} \text { ) } \\
\text { - } \quad \text { kkp (jeżeli chory przyjmował równolegle leki prze- } \\
\text { ciwpłytkowe lub liczba płytek } \leq 60 \mathrm{G} / \mathrm{l} \text { ) } \\
\text { U leczonych dabigatranem: } \\
\text { - } \quad \text { utrzymać adekwatną diurezę } \\
\text { - } \quad \text { rozważyć hemodializę, hemoperfuzję z użyciem } \\
\text { węgla aktywowanego } \\
\text { - } \text { rozważyć podanie idarucizumabu (Praxbind }{ }^{\circledast} \text { ) } \\
\text { w dawce } 5 \text { g i.v. }\end{array}$ & $\begin{array}{l}\text { Rozważyć podanie: } \\
\text { - } \quad \text { PCC (np. Octaplex }{ }^{\circledast}, \text { Beriplex }^{\circledast}, \\
\text { K-Centra }{ }^{\circledast}, \text { Co-Fact }^{\circledast}, \text { Confidex }^{\circledR} \text { ) } \\
\text { w dawce } 25 \text { j./kg mc., powtórzyć } \\
\text { dawke } 1-2 \text { krotnie do dawki } \\
50-75 \text { j./kg mc., jeśli wskazane } \\
\text { klinicznie } \\
\text { - } \quad \text { aPCC (Feiba }{ }^{\circledR} \text { ) w dawce } 50 \text { j./ } \\
\text { /kg mc., maks. } 200 \text { j./kg mc./d. }\end{array}$ \\
\hline
\end{tabular}

Dane naukowe dotyczące równoważności NOAC i VKA w przygotowaniu pacjenta do bezpiecznej kardiowersji są spójne i przekonujące. Zakończone są dwa badania kontrolowane (X-VeRT [26] i ENSURE-AF [27]; badanie EMANATE z apiksabanem jeszcze trwa), metaanalizy i analizy cząstkowe post-hoc badań z dabigatranem, riwaroksabanem i apiksabanem.

Jedyne opublikowane badanie prospektywne dotyczyło przygotowania pacjentów do kardiowersji z użyciem riwaroksabanu w grupie 1504 chorych (20 mg/d. lub 15 mg, jeśli GFR wynosił 30-49 ml/min/ $\mathrm{m}^{2}$ ). Riwaroksaban był równie skuteczny jak warfaryna - incydenty zatorowe obserwowano odpowiednio po 0,51\% i 1,02\% kardiowersji (warfaryna z INR 2-3), przy zbliżonej częstości powikłań krwotocznych (odpowiednio 0,6\% v. 0,8\%) i znamiennie skróconym (średnio o 8 dni) czasie przygotowania do bezpiecznego zabiegu w grupie leczonej NOAC. Podobne wyniki uzyskano w badaniu ENSURE-AF (EdoxabaN vs. warfarin in subjectS UndeRgoing cardiovErsion of Atrial Fibrillation) z zastosowaniem edoksabanu, którego wyniki zaprezentowano na kongresie ESC w Rzymie w sierpniu 2016 roku.

W nielicznych publikacjach retrospektywnych dotyczących przygotowania kardiowersji także potwierdzono podobny profil ryzyka zatorowego dla różnych typów NOAC porównywanych z warfaryną [28, 29]. W dużej subanalizie badania RE-LY (Randomized Evaluation of Long-Term Anticoagulation TherapY) [30] wykazano, że w 1983 kardiowersjach (u 1270 pacjentów) ryzyko powikłań zatorowych wyniosło 0,8\%, 0,3\% i 0,6\%, odpowiednio, dla dabigatranu 2 razy $110 \mathrm{mg}, 2$ razy 150 mg lub warfaryny - różnice nieznamienne. U pacjentów, u których kardiowersję poprzedzono TEE, skrzepliny w uszku lewego przedsionka wykazano analogicznie u 1,8\%, 1,2\%, i 1,1\% ( $p$ = nieznamienne statystycznie [NS]). W japońskim opracowaniu częstość skrzeplin podczas terapii dabigatranem oceniono na $4 \%, z$ reguły przy mniejszej dawce [31]. Podobne wyniki przyniosła analiza kompletnego rejestru 1230 kardiowersji (37\% - dabigatran) w populacji duńskiej [32] - ryzyko 
udaru, zgonu lub istotnego krwawienia do 30 dni od kardiowersji wyniosło $2 \%$ dla warfaryny i $1 \%$ dla dabigatranu (NS). Co bardzo istotne, faktyczny czas przygotowania farmakologicznego wyniósł 4 tygodnie dla dabigatranu, a aż 6,9 tygodnia dla warfaryny $-2,3$ razy większa szansa wykonania prawidłowo przygotowanej kardiowersji w ciągu 4 tygodni u 4 pacjentów przyjmujących dabigatran. W badaniu ze Szwecji ryzyko powikłań zatorowych wyniosło 0,53\% (631 kardiowersji zwykle przy dawce $2 \times 150$ mg) [33]. Bardzo zbliżone pozytywne wyniki uzyskano, poddając analizie kardiowersje u pacjentów leczonych w badaniu ROCKET-AF (Rivaroxaban Once Daily, Oral, Direct Factor Xa Inhibition Compared with Vitamin $K$ Antagonism for Prevention of Stroke and Embolism Trial in Atrial Fibrillation) z riwaroksabanem [34], ARISTOTLE (Apixaban for Reduction in Stroke and Other Thromboembolic Events in Atrial Fibrillation) z apiksabanem [35] oraz ENGAGE-AF TIMI 48 (Effective Anticoagulation with Factor Xa Next Generation in Atrial Fibrillation-Thrombolysis in Myocardial Infarction 48) z edoksabanem [36]; potwierdzono je również w dużych jednoośrodkowych zestawieniach obejmujących wszystkie rodzaje NOAC [37].

Podsumowanie dotychczasowych obserwacji zawierają metaanalizy [38] potwierdzające podobne korzystne wyniki kardiowersji wykonywanych u chorych z badań ROCKET-AF, $\mathrm{X}$-VeRT (eXplore the efficacy and safety of once-daily oral riVaroxaban for the prevention of caRdiovascular events in patients with non-valvular aTrial fibrillation scheduled for cardioversion), ARISTOTLE i RE-LY - ryzyko zatorowości w 2811 kardiowersjach po stosowaniu NOAC wyniosło 0,42\%, w porównaniu z 0,57\% dla warfaryny (1749 zabiegów, NS dla zatorów i ryzyka krwawień) [39]. W najnowszej metaanalizie uwzględniającej także badanie ENGAGE-AF z edoksabanem potwierdzono stanowiącą efekt klasy równoważność NOAC z warfaryną - z nieznamiennie (o 16\%) wyższą ochroną przed incydentami zatorowymi i z nieznamiennie (o 12\%) wyższym ryzykiem krwawień [40]. Opisane dane naukowe znalazły odzwierciedlenie w krajowych charakterystykach produktu leczniczego - dabigatranu, riwaroksabanu i apiksabanu, umożliwiających ich wykorzystanie przed kardiowersją.

Odrębną kwestię stanowi postępowanie w przypadku wykrycia skrzepliny w uszku lewego przedsionka przed planowaną kardiowersją. Standard postępowania polega na kontroli obrazowej po kilku ( $>3$ ) tygodniach standardowego leczenia przeciwzakrzepowego. Spośród NOAC najlepiej przebadano riwaroksaban - dostępne są wyniki prospektywnego badania X-TRA [41] (toczy się podobne badanie RE-LATED AF z dabigatranem) - po 6-8-tygodniowym leczeniu riwaroksabanem w dawce $20 \mathrm{mg} /$ dobe uzyskano rozpuszczenie skrzepliny u 42\% pacjentów [42]. Być może, skuteczniejsze okaże się zwiększone dawkowane riwaroksabanu, na przykład dawka 2 razy $15 \mathrm{mg}$, co zasugerowano w krajowym opisie przypadku [43]. W niedawnej publikacji zasugerowano ponadto, że częstość występowania skrzeplin w przedsionku w przypadku stosowania VKA może być znacznie wyższa niż podczas terapii NOAC [44].

Powyższe dane spójnie wskazują, że NOAC mogą być stosowane w okresie przed kardiowersją i po niej ze skutecznością co najmniej dorównującą VKA. Stały efekt terapii niewymagającej monitorowania INR pozwala, w przeciwieństwie do VKA, skrócić czas oczekiwania pacjenta na bezpieczne przygotowanie przeciwzakrzepowe nawet o kilka tygodni [45].

\section{Zapamiętaj!}

Można stosować NOAC w celu przygotowania pacjenta do kardiowersji analogicznie do VKA; ze względu na krótsze działanie leków nowej generacji podstawowe znaczenie ma jednoznaczne potwierdzenie przez pacjenta nieprzerwanego stosowania leku przez 3 tygodnie poprzedzające zabieg, a w przypadku wątpliwości - wykluczenie skrzepliny metodą TEE. Zastosowanie NOAC zamiast VKA może skracać czas do zgodnego z wytycznymi bezpiecznego przeprowadzenia zabiegu.

\section{Przygotowanie pacjenta do ablacji migotania przedsionków}

Ablacja jest uznaną formą leczenia objawowego napadowego lub przetrwałego AF w przypadku niepowodzenia leczenia antyarytmicznego oraz w sytuacji, gdy leki antyarytmiczne są źle tolerowane lub nieakceptowane przez pacjenta. Ablację w obrębie lewego przedsionka zaliczono do zabiegów wysokiego ryzyka powikłań krwotocznych wraz z jednoczesnym wysokim ryzykiem powikłań zakrzepowo-zatorowych. W danych pochodzących z badań randomizowanych oraz dużych rejestrów ablacji w AF częstość występowania udarów niedokrwiennych/przejściowych napadów niedokrwiennych w okresie zabiegu ablacji okreśIono jako mieszczącą się w przedziale 0-4,2\%, a częstość występowania tamponady serca - 0-2,1\%. Przygotowanie pacjenta do zabiegu obejmuje zarówno moment włączenia, jak i decyzję o odstawieniu leku przeciwzakrzepowego. O ile rozpoczęcie terapii przeciwzakrzepowej nie zależy od rodzaju antykoagulantu, o tyle decyzje o wstrzymaniu lub kontynuacji leczenia przeciwzakrzepowego będą odmienne dla VKA lub NOAC. Minimalne kryteria włączenia antykoagulacji przed zabiegiem ablacji określono w konsensusie ekspertów EHRA/Heart Rhythm Society/European Cardiac Arrhythmia Society i odpowiadają zaleceniom dotyczącym kardiowersji AF [46, 47].

Mimo braku badań kontrolowanych istnieje tendencja do włączania leczenia przeciwzakrzepowego nawet u pacjentów, którzy zgłaszają się na zabieg ablacji z rytmem zatokowym. Pierwszym etapem w rozważaniu strategii 
Tabela 6. Postępowanie przed zabiegiem operacyjnym zależnie od ryzyka krwawienia oraz rodzaju leku z grupy doustnych antykoagulantów niebędących antagonistami witaminy K (NOAC, non-vitamin K oral anticoagulants) (źródło [6])

\section{Dabigatran}

Riwaroksaban, apiksaban, edoksaban

Nie ma istotnego ryzyka krwawienia lub możliwa hemostaza* - wykonanie zabiegu przy najniższym stężeniu leku, tj. $12 \mathrm{~h}$ (dawkowanie $2 \times /$ d.) lub $24 \mathrm{~h}$ (raz/d.) po ostatnim przyjęciu leku

$\begin{array}{lcccc}\begin{array}{l}\text { Klirens kreatyniny } \\ {[\mathrm{ml} / \mathrm{min}]}\end{array} & \begin{array}{c}\text { Niskie ryzyko } \\ \text { krwawienia* }[\mathrm{h}]\end{array} & \begin{array}{c}\text { Wysokie ryzyko } \\ \text { krwawienia* }[\mathrm{h}]\end{array} & \begin{array}{c}\text { Niskie ryzyko } \\ \text { krwawienia* }[\mathrm{h}]\end{array} & \begin{array}{c}\text { Wysokie ryzyko } \\ \text { krwawienia* }[\mathrm{h}]\end{array} \\ >80 & \geq 24 & \geq 48 & \geq 24 & \geq 48 \\ 50-80 & \geq 36 & \geq 72 & \geq 24 & \geq 48 \\ 30-50 & \geq 48 & \geq 96 & \geq 24 & \geq 48 \\ 15-30 & \text { Niewskazany } & \text { Niewskazany } & \text { Brak oficjalnego wskazania do stosowania } & \\ <15 & & & \end{array}$

*Kategorie ryzyka krwawienia przedstawiono w tab. 7

antykoagulacji jest identyfikacja pacjentów z niskim ryzykiem powikłań zakrzepowo-zatorowych (wynik w skali $\mathrm{CHA}_{2} \mathrm{DS}_{2}$-VASc 0 pkt. u mężczyzn, 1 pkt u kobiet). W tej grupie antykoagulacja przed ablacją z powodu AF nie jest wymagana. Natomiast u wszystkich pacjentów z co najmniej 2 punktami w skali $\mathrm{CHA}_{2} \mathrm{DS}_{2}$-VASc należy włączyć antykoagulant przed zabiegiem; dotyczy to również mężczyzn z wynikiem 1-punktowym [48]. W tej grupie pacjentów wymagany jest okres 3 tygodni skutecznej terapii definiowanej jako włączenie NOAC lub VKA przy docelowym INR 2-3 i średnim czasie w oknie terapeutycznym (TTR, time in therapeutic range) ponad $70 \%$. Eksperci zalecaja stosowanie skali SAMe-TT $\mathrm{R}_{2}$ [10] przy wyborze między VKA lub NOAC, warto jednak pamiętać, że wytyczne ESC [5] jako regułę ogólną w niezastawkowym AF zawierają preferencję dla NOAC w stosunku do VKA. Uzyskanie zadowalającego TTR jest prawdopodobne u pacjentów z 0-2 punktami w skali SAMe-TT ${ }_{2} R_{2}$, zatem w tej grupie można ewentualnie włączyć leczenie VKA, pamiętając o powyższych uwagach. W przypadku ponad 2 punktów w skali SAMe- $\mathrm{TT}_{2} \mathrm{R}_{2}$ wartości INR będą prawdopodobnie niestabilne, należy więc rozważyć rutynowe zastosowanie NOAC.

W związku z brakiem możliwości wiarygodnego monitorowania leczenia NOAC skuteczna antykoagulacja zależy głównie od współpracy chorego oraz udzielonych przez lekarza informacji o zasadach stosowania tej grupy leków. Równie ważne jest odnotowanie w dokumentacji chorego, najlepiej w formie oświadczenia osoby poddawanej ablacji, że przyjmowała NOAC i w okresie ostatnich 3 tygodni nie występowały przerwy w tym leczeniu.

Zgodnie z ostatnimi wytycznymi w przypadku stosowania VKA zaleca się kontynuowanie leczenia przeciwzakrzepowego, a optymalna wartość INR to 2-2,5. Eksperci rekomendują nieprzerwane stosowanie VKA przed zabiegiem ablacji, a sam zabieg można przeprowadzić przy wartościach INR 2-3 (dopuszczalne do 3,5) [47].

Dostępne publikacje dotyczące stosowania NOAC w okresie okołozabiegowym zawierają niehomogenne dane, a randomizowane badania oceniające bezpieczeństwo nie- przerwanego stosowania NOAC u pacjentów poddawanych zabiegowi ablacji są w toku. W dotychczas obowiązujących wytycznych zalecano odstawienie NOAC przynajmniej 48 godzin przed zabiegiem ablacji (lub wcześniej - zależnie od CrCl; tab. 6). W przypadku pacjentów przyjmujących NOAC w okresie od odstawienia leku do ablacji nie zaleca się terapii pomostowej heparynami drobnocząsteczkowymi. Dane pochodzące z zakończonych badań nie są jednoznaczne, jednak wskazują, że ryzyko powikłań zakrzepowo-zatorowych oraz krwotocznych w przypadku nieprzerwanego stosowania NOAC w okresie okołozabiegowym jest podobne do ryzyka w przypadku stosowania VKA. Z tego względu w zaleceniach ekspertów dotyczących leczenia przeciwzakrzepowego u pacjentów z prawidłową funkcją nerek poddawanych procedurom elektrofizjologicznym dopuszczono ostatnio przyjęcie ostatniej dawki NOAC 24 godziny przed ablacją. Jednak w przypadku przewlekłej choroby nerek okres ten powinien być dłuższy (tab. 6).

W ramach przygotowania do zabiegu ablacji z powodu AF należy wykonać TEE u każdego pacjenta, u którego istnieją wątpliwości co do odpowiedniej antykoagulacji przez 3 tygodnie poprzedzające zabieg. Powszechną praktyką jest wykonywanie TEE u wszystkich pacjentów, niezależnie od aktualnego rytmu serca czy czynników ryzyka udaru niedokrwiennego mózgu, ponieważ badanie to dostarcza również cennych informacji na temat anatomii przegrody międzyprzedsionkowej oraz żył płucnych.

Powrót do leczenia NOAC po zabiegu ablacji należy rozważyć po 3-4 godzinach od uzyskania hemostazy. Leczenie NOAC należy kontynuować nie krócej niż 8 tygodni po zabiegu u wszystkich pacjentów niezależnie od punktacji w skali $\mathrm{CHA}_{2} \mathrm{DS}_{2}$-VASc oraz rytmu serca [5]. Po upływie 2 miesięcy od ablacji decyzja o ewentualnej kontynuacji leczenia NOAC powinna być podjęta na podstawie skali $\mathrm{CHA}_{2} \mathrm{DS}_{2}$-VASc - u mężczyzn z 0 punktów oraz u kobiet z 1 punktem należy odstawić leczenie NOAC niezależnie od rytmu serca. U pacjentów z wysokim ryzykiem udaru niedokrwiennego leczenie to powinno być kontynuowane po upływie 8 tygodni niezależnie od rytmu serca. 
Tabela 7. Ryzyko krwawienia związane z leczeniem zabiegowym

\begin{tabular}{|c|c|c|}
\hline \multicolumn{3}{|c|}{ Interwencje } \\
\hline Bez konieczności odstawiania VKA/NOAC & Związane z niskim ryzykiem krwawienia & Związane z wysokim ryzykiem krwawienia \\
\hline Ekstrakcja 1-3 zębów & Ekstrakcja $\geq 4$ zębów & $\begin{array}{l}\text { Znieczulenie zewnątrzoponowe/podpajęczy- } \\
\text { nówkowe, nakłucie lędźwiowe }\end{array}$ \\
\hline Operacje zaćmy lub jaskry & $\begin{array}{l}\text { Biopsja (badanie endoskopowe pęcherza, } \\
\text { gruczołu krokowego) }\end{array}$ & Biopsja (wątroby, nerki) \\
\hline Endoskopia bez zabiegu chirurgicznego & Angiografia & Duży zabieg chirurgiczny \\
\hline Powierzchowny zabieg chirurgiczny & $\begin{array}{l}\text { Ablacja cewnikowa prądem o częstotliwo- } \\
\text { ści radiowej }\end{array}$ & $\begin{array}{l}\text { Złożona ablacja lewostronna (AF, lewa ko- } \\
\text { mora) }\end{array}$ \\
\hline
\end{tabular}

VKA (vitamin K antagonists) - antagoniści witaminy K; NOAC (non-vitamin K oral anticoagulants) - doustne antykoagulanty niebędące antagonistami witaminy K; AF (atrial fibrillation) - migotanie przedsionków

\section{Zapamiętaj!}

Kierując się punktacją w skali $\mathrm{CHA}_{2} \mathrm{DS}_{2}$-VASc, leczenie NOAC należy włączyć 3 tygodnie przed zabiegiem ablacji. Ze względu na brak jednoznacznych wyników badań randomizowanych leczenie to należy odstawić przynajmniej 24 godziny przed zabiegiem ablacji (lub wcześniej, zależnie od funkcji nerek).

\section{Pacjent przyjmujący NOAC przed zabiegiem chirurgicznym}

Każde leczenie przeciwzakrzepowe, także z użyciem NOAC [48], wiąże się ze zwiększonym ryzykiem krwawień podczas zabiegów operacyjnych. Postępowanie u pacjentów leczonych NOAC poddawanych planowemu lub pilnemu zabiegowi chirurgicznemu może być czasem trudne. Dlatego właściwe zalecenia powinny się odnosić do konkretnych sytuacji klinicznych i zależeć od dokładnej znajomości zastosowanego leku, jego farmakodynamiki, farmakokinetyki, oceny efektywności przeciwkrzepliwej w kontekście rozległości i pilności zabiegu chirurgicznego. Sam zabieg wpływa na układ hemostazy, powodując wzrost krzepliwości poprzez zwiększenie stężenia fibrynogenu, czynników krzepnięcia czy liczby płytek w stopniu zależnym od rozległości zabiegu i czasu jego trwania. Dlatego tak ważny jest nadzór nad pacjentem w okresie okołooperacyjnym prowadzony wspólnie przez kardiologa, anestezjologa i chirurga [49].

Podstawowym zadaniem jest określenie ryzyka zabiegu operacyjnego związanego z możliwymi powikłaniami kardiologicznymi i krwotocznymi. W celu podjęcia właściwych decyzji terapeutycznych należy oszacować ryzyko powikłań zakrzepowo-zatorowych. W związku z powyższym zabiegi chirurgiczne można podzielić na cechujące się niskim, umiarkowanym i wysokim ryzykiem wystapienia incydentu sercowo-naczyniowego w okresie 30-dniowym. Niska częstość występowania incydentów to ryzyko zgonu z przyczyn sercowo-naczyniowych niższe od 1\%, umiarkowane ryzyko - 1-5\%, natomiast wysokie ryzyko określa się jako przekraczające $5 \%$.
Istotnym elementem oceny jest oszacowanie ryzyka powikłań krwotocznych związanych z zaplanowanym zabiegiem operacyjnym (tab. 7). Zabiegi chirurgiczne podzielono więc na kategorie niskiego i wysokiego ryzyka powikłań krwotocznych. Niskim ryzykiem są obarczone zabiegi wykonywane technikami laparoskopowymi (diagnostycznymi - gastroskopia, kolonoskopia oraz terapeutycznymi - cholecystektomia, leczenie kamicy nerkowej), zabiegi biopsyjne (biopsja prostaty lub pęcherza moczowego, biopsja aspiracyjna szpiku kostnego, biopsja węzła chłonnego, punkcja stawu), badania inwazyjne (elektrofizjologiczne, koronarografia lub angiografia), małe zabiegi inwazyjne (implantacja kardiostymulatora lub kardiowertera-defibrylatora, większość procedur stomatologicznych, dermatologicznych i okulistycznych). Do grupy o wysokim ryzyku należą zabiegi z zakresu chirurgii jamy brzusznej i klatki piersiowej (kardiochirurgia, chirurgia naczyniowa), duże zabiegi ortopedyczne, biopsja wątroby lub nerki, przezcewkowa resekcja gruczołu krokowego oraz złożona ablacja lewostronna: izolacja żył płucnych, ablacja podłoża częstoskurczu komorowego. Do tego typu zabiegów zalicza się również znieczulenie dokanałowe lub zewnątrzoponowe, diagnostyczne nakłucie lędźwiowe i zabiegi neurochirurgiczne (wewnątrzczaszkowe oraz chirurgia rdzenia kręgowego). Wśród zabiegów kardiologicznych należy do nich na przykład złożona ablacja lewostronna - izolacja żyły płucnej lub ablacja podłoża częstoskurczu komorowego [48].

U chorych obciążonych wysokim ryzykiem powikłań zakrzepowo-zatorowych nawet krótkotrwałe przerwanie antykoagulacji może doprowadzić do wzrostu liczby powikłań. Dlatego na podstawie powyższej klasyfikacji ustalono rodzaj interwencji niewymagających odstawienia leku przeciwzakrzepowego (tzw. małe zabiegi stomatologiczne, dermatologiczne i okulistyczne) - takie procedury powinny być wykonane przy minimalnych stężeniach NOAC, czyli tuż przed przyjęciem kolejnej dawki leku. Należy podkreślić, że rutynowe odstawianie leków przeciwzakrzepowych lub przeciwpłytkowych przed takimi zabiegami zwiększa ryzyko zakrzepicy u pacjenta i jest błędem. 


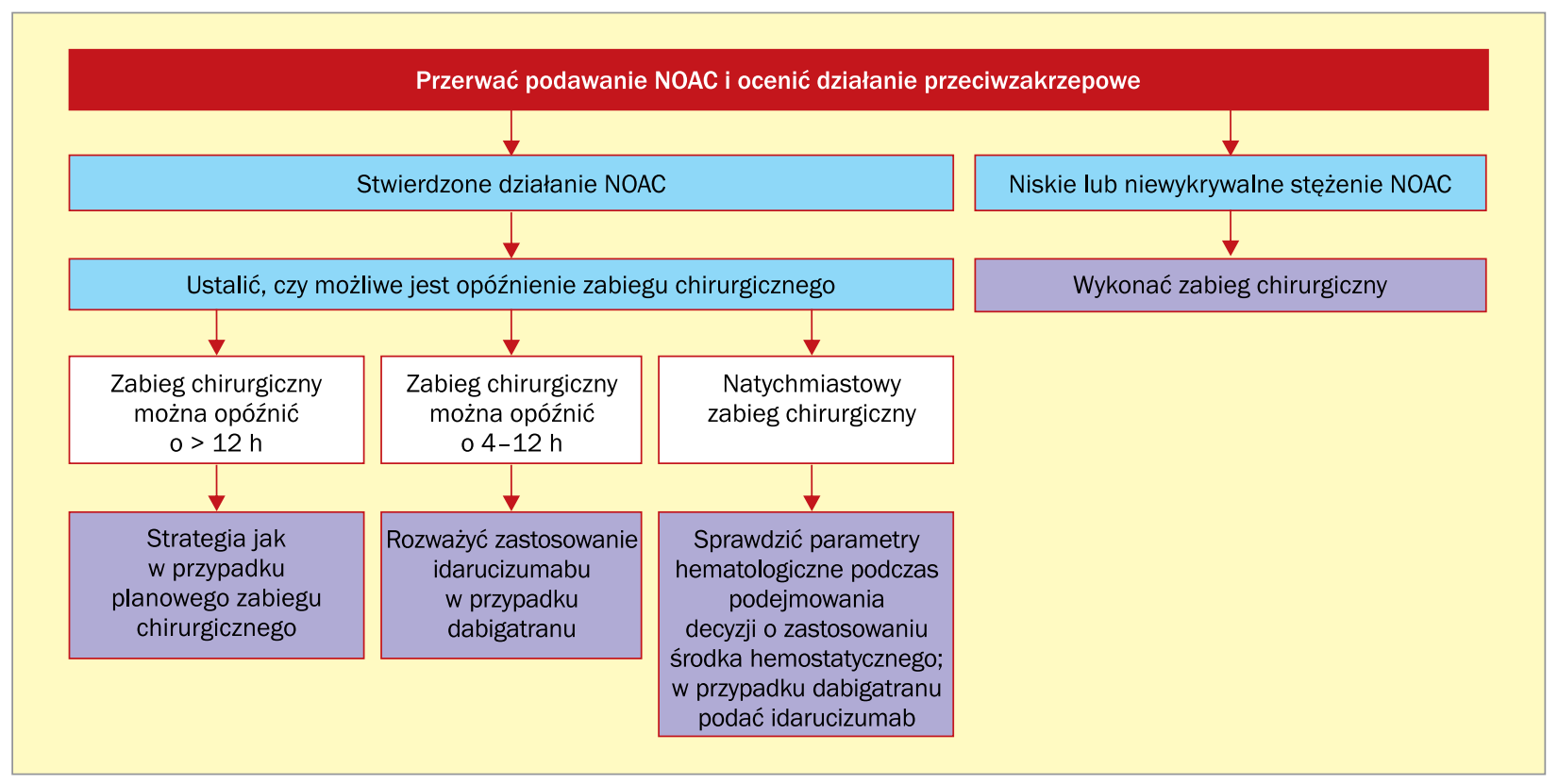

Rycina 1. Przykładowy algorytm postępowania w przypadku pilnego zabiegu chirurgicznego u pacjentów leczonych doustnymi antykoagulantami niebędącymi antagonistami witaminy K (NOAC, non-vitamin K oral anticoagulants)

Zabiegi obarczone wysokim ryzykiem powikłań krwotocznych wymagają przerwania antykoagulacji na odpowiedni czas, który zależy od rodzaju stosowanego NOAC, $\mathrm{CrCl}$ i ryzyka krwawienia związanego z typem zabiegu. Ogólnie zaleca się przerywanie podawania NOAC przed operacją na czas odpowiadający 2-3 biologicznym okresom półtrwania przy niskim ryzyku krwawienia oraz 4-5 okresom przy wysokim ryzyku krwawienia. Jednakże u chorych z przewlekła chorobą nerek oraz wysokim ryzykiem powikłań krwotocznych zaprzestanie podawania NOAC przed operacją ustala się indywidualnie. Punktem wyjściowym jest oszacowanie filtracji kłębuszkowej - w kluczowych badaniach NOAC wykorzystywano wzór Cockrofta-Gaulta, choć obecnie preferuje się wzór CKD-EPI (Chronic Kidney-Disease Epidemiology Collaboration) lub MDRD (Modification of Diet in Renal Disease). U pacjentów poddawanych zabiegom związanym z niskim ryzykiem powikłań krwotocznych riwaroksaban i apiksaban należy odstawić na 24 godziny, a z wysokim ryzykiem krwawienia - na 48 godzin, niezależnie od $\mathrm{CrCl}$. Czas przerwania stosowania dabigatranu zależy od funkcji nerek i może sięgać nawet 96 godzin - dokładne dane dla dabigatranu przedstawiono $w$ tabeli 6 . Należy dodać, że u chorych obciążonych wysokim ryzykiem powikłań krwotocznych wskazane jest oznaczenie APTT przed pilną operacją - prawidłowy wynik badania wskazuje na niezaburzające krzepnięcie stężenie dabigatranu. Należy podkreślić, że w przypadku stosowania NOAC problem terapii pomostowej praktycznie nie istnieje. Nie zaleca się stosowania terapii pomostowej heparynami drobnocząsteczkowymi czy heparyną niefrakcjonowana, ponieważ NOAC działają krótko. Zgodnie ze stanowiskiem ekspertów odstawianie NOAC na dłużej niż 5-7 dni i podawanie heparyn jako antykoagulacji pomostowej naraża jedynie chorego na krwawienie, przy braku danych na większą skuteczność leczenia. Jedyną zatem sytuacją kliniczną właściwą do zastosowania takiej terapii pomostowej może być nieplanowane opóźnienie operacji.

Osobnym zagadnieniem jest postępowanie w sytuacji zagrożenia życia i konieczności pilnej interwencji chirurgicznej (ryc. 1). Obecnie możliwości odwrócenia działania NOAC obejmują PCC, aPCC oraz swoiste antidota - obecnie jedynie idarucizumab dla dabigatranu.

U pacjentów leczonych riwaroksabanem zastosowanie PCC we wstępnej dawce 25-50 j./kg mc. jest już klinicznie efektywne, gdyż w ciągu 20 min od zakończenia podawania leku dochodzi do normalizacji PT i możliwości przeprowadzenia procedury leczenia chirurgicznego. Również podanie aPCC koryguje wszystkie nieprawidłowe wskaźniki generacji trombiny. Podobny efekt uzyskuje się kilku minut po podaniu idarucizumabu w dawce $5 \mathrm{~g}$ dożylnie u chorych przyjmujących dabigatran - dochodzi do przywrócenia działania przeciwkrzepliwego ocenianego jako normalizacja dTT lub ECT. Należy dodać, że zastosowanie PCC i aPPC u pacjentów przyjmujących dabigatran jest częściowo skuteczne klinicznie, ale nie normalizuje TT ani APTT. Nie wykazano korzyści z rutynowego zastosowania preparatów zawierających rekombinowany czynnik VIla w celu odwrócenia działania riwaroksabanu i dabigatranu.

Reasumując, należy podkreślić, że pacjent leczony NOAC w przypadku wykonania planowanego zabiegu ope- 
Podsumowanie - zalecenia praktyczne

1. Leki przeciwzakrzepowe nowej generacji - NOAC, będące doustnymi antagonistami trombiny lub aktywnego czynnika X, powinny być preferowanym wyborem w zapobieganiu zatorowości sercopochodnej i VTE/PE. Przeciwwskazaniami do stosowania NOAC są mechaniczna zastawka serca, istotne zwężenie zastawki mitralnej oraz zaawansowana niewydolność nerek z GFR poniżej $15 \mathrm{ml} / \mathrm{min}$.

2. Doustne antykoagulanty nowej generacji zwiększają skuteczność i bezpieczeństwo leczenia przeciwzakrzepowego, po uwzględnieniu właściwości konkretnego leku, wieku i funkcji nerek pacjenta oraz możliwych interakcji z innymi lekami. Konieczne jest regularne monitorowanie $\mathrm{CrCl}$.

3. Wybór konkretnego leku przeciwzakrzepowego powinien wynikać z merytorycznej dyskusji z pacjentem uwzględniającej aspekty medyczne, ekonomiczne i współdziałanie terapeutyczne. Aspekty medyczne, które mogą ukierunkowywać wybór leku, to funkcja nerek, bardzo wysokie ryzyko zakrzepowe lub wywiad zatorowości przy innym antykoagulancie oraz wysokie ryzyko krwotoczne.

4. Stosowanie doustnych bezpośrednich inhibitorów lla i Xa nie wymaga rutynowego monitorowania parametrów krzepnięcia krwi.

5. Przy zmianie rodzaju leku przeciwzakrzepowego (VKA/NOAC) istotne znaczenie mają zachowanie ciąłej skuteczności leczenia i minimalizacja ryzyka powikłań krwotocznych w oparciu o schematy kontroli wynikające z farmakokinetyki leków.

6. Kluczowe znaczenie dla opanowania krwawienia u pacjenta leczonego NOAC, przy ograniczonych możliwościach rutynowej oceny siły działania przeciwzakrzepowego, mają: pełna ocena kliniczna, identyfikacja podłoża krwawienia, oszacowanie czasu niezbędnego do eliminacji leku, próba wyrównania niedoborów czynników układu krzepnięcia, a w przypadku dabigatranu dodatkowo możliwość dializy lub podania swoistego antidotum - idarucizumabu.

7. Trzytygodniowe stosowanie NOAC może być stosowane w celu przygotowania pacjenta do kardiowersji, analogicznie jak w przypadku VKA - ze względu na krótsze działanie leków nowej generacji podstawowe znaczenie ma jednoznaczne potwierdzenie przez pacjenta nieprzerwanego stosowania leku, a w przypadku wątpliwości wykluczenie skrzepliny metodą TEE.

8. Przed zabiegiem ablacji AF należy podjąć decyzję o włączeniu leczenia NOAC na 3 tygodnie, kierując się punktacją w skali $\mathrm{CHA}_{2} \mathrm{DS}_{2}$-VASc. Ze względu na brak jednoznacznych wyników badań randomizowanych leczenie NOAC należy odstawić przynajmniej 24 godziny przed zabiegiem ablacji (lub wcześniej, zależnie od funkcji nerek).

9. Rutynowe odstawianie leków przeciwzakrzepowych przed zabiegami o niskim ryzyku krwawień jest nieuzasadnione i może zwiększać ryzyko powikłań zakrzepowo-zatorowych.

10. Przygotowanie pacjenta leczonego NOAC do zabiegu operacyjnego obarczonego istotnym ryzykiem krwawienia wymaga wiedzy o tempie eliminacji ostatniej podanej dawki leku (funkcja nerek), czasie możliwego odroczenia operacji i właściwościach stosowanego leku przeciwzakrzepowego, a w sytuacjach pilnych może wymagać interwencji farmakologicznej (podanie czynników krzepnięcia lub antidotum).

racyjnego wymaga właściwego przygotowania, ze szczególnym uwzględnieniem rodzaju procedury chirurgicznej, potencjalnego ryzyka zakrzepowo-zatorowego z jednej strony i krwotocznego z drugiej. W przypadku pilnych zabiegów należy podjąć próby oceny działania NOAC w zależności od stosowanego leku. Decyzje terapeutyczne dotyczące natychmiastowego odwrócenia działania NOAC powinny być podejmowane ze szczególną ostrożnością, po dokładnej analizie danej sytuacji klinicznej i w oparciu o wspólną konsultację kardiologa, anestezjologia i chirurga.

\section{Konflikt interesów}

JDK: honoraria za wykłady, udział w komitetach doradczych: Bayer, Boehringer Ingelheim, Pfizer.
RD: honoraria za wykłady: Bayer, Boehringer Ingelheim.

MB: brak konfliktu interesów.

AM: honoraria za wykłady, udział w komitetach doradczych: Aspen, Bayer, Boehringer Ingelheim, Pfizer.

MW: brak konfliktu interesów.

KJF: honoraria za wykłady, udział w komitetach doradczych: Aspen, Bayer, Boehringer Ingelheim, MSD, Pfizer, Sanofi Aventis.

PL: honoraria za wykłady, udział w komitetach doradczych: Bayer, Boehringer Ingelheim.

DK: honoraria za wykłady, udział w komitetach doradczych: Bayer, Boehringer Ingelheim, MSD, Pfizer, Sanofi Aventis.

BWK: honoraria za wykłady, udział w komitetach doradczych: Aspen, Bayer, Boehringer Ingelheim, MSD, Orion, Pfizer. 


\section{Abstract}

This document is a statement from Cardiovascular Pharmacotherapy Section of the Polish Cardiac Society regarding the practical approach to therapy with novel oral anticoagulants - thrombin antagonists and Xa antagonists, based upon most recent scientific information including European Society of Cardiology guidelines 2016 and recommendations from European Heart Rhythm Association.

Key words: NOAC, anticoagulants, atrial fibrillation

Folia Cardiologica 2016; 11, 5: 377-393

\section{Piśmiennictwo}

1. Pruszczyk P., Stępińska J., Banasiak W. i wsp. [New oral anticoagulants in the prevention of embolic complications in patients with atrial fibrillation. Polish Cardiac Society, Polish Neurological Society and Working Group on Haemostasis of the Polish Society of Haematologists and Transfusiologists consensus statement]. Kardiol. Pol. 2012; 70: 979-988.

2. Heidbuchel H., Verhamme P., Alings M. i wsp. European Heart Rhythm Association practical guide on the use of new oral anticoagulants in patients with non-valvular atrial fibrillation. Europace 2013; 15: 625-651.

3. Stępińska J., Wożakowska-Kapłon B., Pruszczyk P., Kalarus Z. Non-vitamin K oral antagonist no more new! Kardiol. Pol. 2014; 72: 854-855.

4. Ruff C.T., Giugliano R.P., Braunwald E. i wsp. Comparison of the efficacy and safety of new oral anticoagulants with warfarin in patients with atrial fibrillation: a meta-analysis of randomised trials. Lancet 2014; 383: 955-962.

5. Kirchhof P., Benussi S., Kotecha D. i wsp. 2016 ESC Guidelines for the management of atrial fibrillation developed in collaboration with EACTS: the Task Force for the management of atrial fibrillation of the European Society of Cardiology (ESC) Developed with the special contribution of the European Heart Rhythm Association (EHRA) of the ESC endorsed by the European Stroke Organisation (ESO). Eur. Heart J. 2016 Aug 27 [złożone do druku].

6. Heidbuchel H., Verhamme P., Alings M. i wsp. Updated European Rhythm Association practical guide on the use of non-vitamin $\mathrm{K}$ antagonist anticoagulants in patients with non-valvular atrial fibrillation. Europace 2015; 17: 1467-1507.

7. Morimoto T., Crawford B., Wada K., Ueda S. Comparative efficacy and safety of novel oral anticoagulants in patients with atrial fibrillation: a network meta-analysis with the adjustment for the possible bias from open label studies. J. Cardiol. 2015; 66: 466-474.

8. Providência R., Grove E.L., Husted S. i wsp. A meta-analysis of phase III randomized controlled trials with novel oral anticoagulants in atrial fibrillation: comparisons between direct thrombin inhibitors vs. factor Xa inhibitors and different dosing regimens. Thromb. Res. 2014; 134: 1253-1264.

9. Camm A.J., Lip G.Y., De Caterina R. i wsp. 2012 focused update of the ESC Guidelines for the management of atrial fibrillation: an update of the 2010 ESC Guidelines for the management of atrial fibrillation. Developed with the special contribution of the European Heart Rhythm Association. Eur. Heart J. 2012; 33: 2719-2747.
10. Apostolakis S., Sullivan R.M., Olshansky B., Lip G.Y. Factors affecting quality of anticoagulation control among patients with atrial fibrillation on warfarin: the SAMe- $\mathrm{TT}_{2} \mathrm{R}_{2}$ score. Chest 2013; 144: 1555-1563.

11. Ezekowitz M.D., Nagarakanti R., Noack H. i wsp. Comparison of dabigatran and warfarin in patients with atrial fibrillation and valvular heart disease. The RE-LY trial. Circulation 2016; 134: 589-598.

12. Kovacs R.J., Flaker G.C., Saxonhouse S.J. i wsp. Practical management of anticoagulation in patients with atrial fibrillation. J. Am. Coll. Cardiol. 2015; 65: 1340-1360.

13. Andreotti F., Rocca B., Husted S. i wsp.; on behalf of the ESC Thrombosis Working Group. Antithrombotic therapy in the elderly: expert position paper of the European Society of Cardiology Working Group on Thrombosis. Eur. Heart J. 2015; 36: 3238-3249.

14. Cotton B.A., McCarthy J.J., Holcomb J.B. Acutely injured patients on dabigatran. N. Engl. J. Med. 2011; 365: 2039-2040.

15. van Ryn J., Stangier J., Haertter S. i wsp. Dabigatran etexilate: a novel, reversible, oral direct thrombin inhibitor: interpretation of coagulation assays and reversal of anticoagulant activity. Thromb. Haemost. 2010; 103: 1116-1127.

16. Mani H., Hesse C., Stratmann G. i wsp. Rivaroxaban differentially influences ex vivo global coagulation assays based on the administration time. Thromb. Haemost. 2011; 106: 156-164.

17. Hillarp A., Baghaei F., Fagerberg Blixter I. i wsp. Effects of the oral, direct factor Xa inhibitor rivaroxaban on commonly used coagulation assays. J. Thromb. Haemost. 2011; 9: 133-139.

18. Tripodi A. The laboratory and the new oral anticoagulants. Clin. Chem. 2013; 59: 353-362.

19. Baglin T. The role of the laboratory in treatment with new oral anticoagulants. J. Thromb. Haemost. 2013; 11 (supl. 1): 122-128.

20. Beyer-Westendorf J., Gelbricht V., Förster K. i wsp. Safety of switching from vitamin $\mathrm{K}$ antagonists to dabigatran or rivaroxaban in daily care - results from the Dresden NOAC registry. Br. J. Clin. Pharmacol. 2014; 78: 908-917.

21. Rognoni C., Marchetti M., Quaglini S. i wsp. Apixaban, dabigatran, and rivaroxaban versus warfarin for stroke prevention in non-valvular atrial fibrillation: a cost-effectiveness analysis. Clin. Drug Investig. 2014; 34: 9-17.

22. Schulman S., Angeras U., Bergqvist D. i wsp. Definition of major bleeding in clinical investigations of antihemostatic medicinal products in surgical patients. J. Thromb. Heamost. 2010; 8: 202-204. 
23. Pollack C.V., Reilly P.A., Eikelboom J. i wsp. Idarucizumab for dabigatran reversal. N. Engl. J. Med. 2015; 373: 511-520.

24. Siegal D.M., Curnutte J.T., Connolly S.J. i wsp. Andexanet alfa for the reversal of factor Xa inhibitor activity. N. Engl. J. Med. 2015; 373: 2413-2424.

25. Ansell J.E., Bakhru S.H., Laulicht B.E. i wsp. Use of PER977 to reverse the anticoagulant effect of edoxaban. N. Engl. J. Med. 2014; 371: 2141-2142.

26. Cappato R., Ezekowitz M.D., Klein A.L. i wsp. Rivaroxaban vs. vitamin $K$ antagonists for cardioversion in atrial fibrillation. Eur. Heart J. 2014; 35: 3346-3355.

27. Lip G.Y., Merino J., Ezekowitz M. i wsp. A prospective evaluation of edoxaban compared to warfarin in subjects undergoing cardioversion of atrial fibrillation: the EdoxabaN vs. warfarin in subjectS UndeRgoing cardiovErsion of Atrial Fibrillation (ENSURE-AF) study. Am. Heart J. 2015; 169: 597-604.e5.

28. Coleman C.M., Khalaf S., Mould S. i wsp. Novel oral anticoagulants for DC cardioversion procedures: utilization and clinical outcomes compared with warfarin. Pacing Clin. Electrophysiol. 2015; 38: 731-737.

29. Kochhäuser S., Khaykin Y., Beardsall J. i wsp. Comparison of outcomes after cardioversion or atrial fibrillation ablation in patients with differing periprocedural anticoagulation regimens. Can. J. Cardiol. 2014; 30: 1541-1546.

30. Nagarakanti R., Ezekowitz M.D., Oldgren J. i wsp. Dabigatran versus warfarin in patients with atrial fibrillation: an analysis of patients undergoing cardioversion. Circulation 2011; 123: 131-136.

31. Mitamura H., Nagai T., Watanabe A. i wsp. Left atrial thrombus formation and resolution during dabigatran therapy: a Japanese Heart Rhythm Society report. J. Arrhythm. 2015; 31: 226-231.

32. Pallisgaard J.L., Lindhardt T.B., Hansen M.L. i wsp. Cardioversion and risk of adverse events with dabigatran versus warfarin - a nationwide cohort study. PLoS One 2015; 10: e0141377.

33. Johansson A.K., Juhlin T., Engdahl J. i wsp. Is one month treatment with dabigatran before cardioversion of atrial fibrillation sufficient to prevent thromboembolism? Europace 2015; 17: 1514-1517.

34. Piccini J.P., Stevens S.R., Lokhnygina Y. i wsp. Outcomes after cardioversion and atrial fibrillation ablation in patients treated with rivaroxaban and warfarin in the ROCKET AF trial. J. Am. Coll. Cardiol. 2013; 61: 1998-2006.

35. Flaker G., Lopes R.D., Al-Khatib S.M. i wsp. Efficacy and safety of apixaban in patients after cardioversion for atrial fibrillation: insights from the ARISTOTLE trial (Apixaban for Reduction in Stroke and Other Thromboembolic Events in Atrial Fibrillation). J. Am. Coll. Cardiol. 2014; 63: 1082-1087.

36. Plitt A., Ezekowitz M.D., De Caterina R. i wsp. Cardioversion of atrial fibrillation in ENGAGE AF-TIMI 48. Clin. Cardiol. 2016; 39: 345-346.

37. Coleman C.M., Khalaf S., Mould S. i wsp. Novel oral anticoagulants for dc cardioversion procedures: utilization and clinical outcomes compared with warfarin. Pacing Clin. Electrophysiol. 2015; 38: 731-737.

38. Yadlapati A., Groh C., Passman R. Safety of short-term use of dabigatran or rivaroxaban for direct-current cardioversion in patients with atrial fibrillation and atrial flutter. Am. J. Cardiol. 2014; 113: 1362-1363.

39. Sen P., Kundu A., Sardar P. i wsp. Outcomes after cardioversion in atrial fibrillation patients treated with non-vitamin $\mathrm{K}$ antagonist oral anticoagulants (NOACs): insights from a meta-analysis. Am. J. Cardiovasc. Drugs 2016; 16: 33-41.

40. Renda G., Zimarino M., Ricci F. i wsp. Efficacy and safety of non-vitamin $\mathrm{K}$ antagonist oral anticoagulants after cardioversion for nonvalvular atrial fibrillation. Am. J. Med. 2016 Jun 2. pii: S0002-9343(16)30539-3.

41. Lip G.Y., Hammerstingl C., Marin F. i wsp. Rationale and design of a study exploring the efficacy of once-daily oral rivaroxaban (X-TRA) on the outcome of left atrial/left atrial appendage thrombus in nonvalvular atrial fibrillation or atrial flutter and a retrospective observational registry providing baseline data (CLOT-AF). Am. Heart J. 2015; 169: 464-471.e2.

42. Lip G.Y.H., Hammerstingl C., Marin F. i wsp. Left atrial thrombus resolution in atrial fibrillation or flutter: results of a prospective study with rivaroxaban (X-TRA) and a retrospective observational registry providing baseline data (CLOT-AF). Am. J. Cardiol. 2016; 178: $126-134$.

43. Piotrowski R., Zaborska B., Baran J. i wsp. Rivaroxaban twice daily for lysis of left atrial appendage thrombus: a potential new therapeutic option. Pol. Arch. Med. Wewn. 2016; 126: 430-431.

44. Zylla M.M., Pohlmeier M., Hess A. i wsp. Prevalence of intracardiac thrombi under phenprocoumon, direct oral anticoagulants (dabigatran and rivaroxaban), and bridging therapy in patients with atrial fibrillation and flutter. Am. J. Cardiol. 2015; 115: 635-640.

45. Choo W.K., Fraser S., Padfield G. i wsp. Dabigatran improves the efficiency of an elective direct current cardioversion service. Br. J. Cardiol. 2014; 21: 29-32.

46. Calkins H., Kuck K.H., Cappato R. i wsp. 2012 HRS/EHRA/ECAS EXpert consensus statement on catheter and surgical ablation of atrial fibrillation: recommendations for patient selection, procedural techniques, patient management and follow-up, definitions, endpoints, and research trial design. Europace 2012; 14: 528-606.

47. Sticherling C., Marin F., Birnie D. i wsp. Antithrombotic management in patients undergoing electrophysiological procedures: a European Heart Rhythm Association (EHRA) position document endorsed by the ESC Working Group Thrombosis, Heart Rhythm Society (HRS), and Asia Pacific Heart Rhythm Society (APHRS). Europace 2015; 17: $1197-1214$.

48. Sardar P., Chatterjee S., Lavie C.J. i wsp. Risk of major bleeding in different indications for new oral anticoagulants: insights from a meta-analysis of approved dosages from 50 randomized trials. Int. J. Cardiol. 2015; 179: 279-287.

49. Kristensen S.D., Knuuti J., Sarasate A. i wsp. 2014 ESC/ESA Guidelines on non-cardiac surgery: cardioVAScular assessment and management: the Joint Task Force on non-cardiac surgery of the European Society Of Cardiology (ESC) and European Society of Anaesthesiology (ESA). Eur. Heart J. 2014; 35: 2383-2431. 